\title{
Hvað var trúarlegt við Tyrkjaránið?
}

\section{Formáli}

Tyrkjaránið er alkunnur atburður á Íslandi en hér skulu dregnar fram meginlínur í atburðarásinni. Reynt verður að skýra pau atriði sem vísað er til í meginefni greinarinnar. Víða annars staðar má afla sér vitneskju um atburðina. ${ }^{1}$

Sjórán hafa tíðkast um heimsins höf frá örófi alda. Við Miðjarðarhafið og í nágrenni pess voru nokkrar hafnarborgir sérlega öflugar á pessum vettvangi á sögutíma Tyrkjaránsins og paðan herjuðu korsarar í nafni og með leyfi stjórnvalda á hverjum stað, enda var pessi starfsemi talin vera páttur í lögmætum hernaði pessara staða. Kristnir korsarar voru máttugastir á Möltu en undir íslömskum formerkjum voru borgirnar Salé-Rabat í Marokkó og Algeirsborg fremstar í flokki. Hin síðarnefnda heyrði undir Tyrkjaveldi Ósmana og par voru tyrkneskar hersveitir janissara og landstjóri (pasha) Tyrkjasoldáns. Salé stóð utan Tyrkjaveldis en á báðum stöðum var fjöldi Evrópumanna sem höfðu tekið íslamska trú og lögðu lið í ránsferðum og hernaði auk friðsamlegri starfa heima fyrir.

Korsarar frá Salé og Algeirsborg tóku að herja á Atlantshafi skömmu eftir 1600 og sumarið 1627 lögðu peir leið sína til Íslands. Frá Salé kom eitt skip og var fólki og fémæti rænt í Grindavík og tilraun gerð til að ráðast að Bessastöðum en án árangurs. Frá Algeirsborg komu prjú skip og réðust af miklum krafti á sunnanverða Austfirði og Vestmannaeyjar. Samtals voru hátt í 400 manns hertekin og um 40 felld. Hin herteknu voru seld á prælamarkaði en jafnframt var leyft að kaupa flestum peirra frelsi gegn lausnargjaldi. Um 40 peirra voru pannig endurleyst fyrir tilstilli kirkju, konungs og einstaklinga. Dekktust peirra er Guðríður Símonardóttir sem fékk viðurnefnið Tyrkja-Gudda en hún varð ástkona og síðan eiginkona Hallgríms Péturssonar sálmaskálds.

Miklar heimildir eru til um Tyrkjaránið og verður vitnað til peirra hér á eftir. Kláus Eyjólfssonar lögréttumaður og bóndi var fyrstur að skrá frásögn af ráninu í Vestmannaeyjum. Ólafur Egilsson prestur í Vestmannaeyjum ritaði ferðasögu sína frá pví að hann var hertekinn í Vestmannaeyjum par til honum var fljótlega sleppt í Algeirsborg og hann komst til Kaupmannahafnar og paðan til Íslands. Björn Jónsson á Skarðsá í Skagafirði tók saman heildstæða sögu Tyrkjaránsins að beiðni Porláks Skúlasonar biskups á Hólum árið 1643 og

\footnotetext{
${ }^{1}$ Handhægt er að lesa stuttar yfirlitsgreinar á Vísindavefnum um atburðina. Jón Porkelsson pjóðskjalavörður safnaði, ritstýrði og kom á prent ítarlegu safni frumheimilda undir heitinu Tyrkjaránið á Íslandi 1627 og gaf út á vegum Sögufélags í fjórum heftum á árunum 1906 til 1909. Hér verður petta heimildasafn mikið notað og vísað til einstakra frásagna og annarra skjala í safninu undir nöfnum frumhöfunda og heita Jóns á skjölum eða með einfaldaðri efnislegri fyrirsögn. Ferðasaga (reisubók) séra Ólafs Egilssonar er ekki til í frumriti en hins vegar í mörgum afskriftum. Jón borkelsson flokkaði pær í tvennt og kallaði A og B. Hér er B-gerðin notuð par sem ég (og Jón) tel hana nær frumritinu. Svipað gildir um frásögn Kláusar Eyjólfssonar af ráninu í Vestmannaeyjum. Frumritin eru ekki til lengur en margar og ólíkar afskriftir hafa varðveist. Pær eru með svo ólíku sniði að Jón Porkelsson setti pær í fjóra flokka, A-D. Hér er vísað í pessa flokkun Jóns. Heimildaútgáfa Jóns er aðgengileg á stafrænu formi á https://baekur.is. Nokkur frumskjöl til viðbótar við safn Jóns hafa komið út síðan.
} 
byggði hana á fyrri ritum, sendibréfum og fleira efni. Margir urðu til að yrkja um atburðina svo sem Guðmundur Erlendsson prestur á Felli í Skagafirði en hann orti Ræningjarímur sem hafa 305 erindi að geyma.

Um Tyrkjaránið hef ég fjallað á marga vegu og um marga pætti pess, svo sem um bakgrunn pess í Norður-Afríku, forystumenn herferðarinnar, atburðarásina, frásagnirnar um ránið, aðgerðir til útlausnar hertekinna og minningu ránsins í frásögnum, pjóðsögum og örnefnum. Nokkuð hef ég drepið á trúarlega hlið pessara atburða en hér skal tekið fastar á peim páttum. Engum getur komið á óvart sem fjallar um sautjándu öld að umfjöllun samtímamanna atburðanna sé með trúarlegu ívafi. Trúarbragðafræðingurinn Karen Armstrong orðar petta pannig með nokkrum hálfkæringi: „Before about 1700 religion permeated the whole of life so thoroughly that taking "religion" out of "politics" would be like trying to extract gin from a cocktail."

Hér er ætlunin að sundurgreina pennan ,kokteil“ og meta marga pætti atburðanna í ljósi pess hver trúarleg umgjörð peirra var talin vera og hve trúarlegur skilningur og orðfæri var stór páttur í skrifum manna um atburðina. Athyglinni verður beint að reynslu, athöfnum, skilningi og ritun samtímanna á sautjándu öld, einkum Íslendinga, og flest í beinum tengslum við Tyrkjaránið en pó er seilst út fyrir pað og út fyrir öldina pegar pörf er á. Margt er hér ekki fjallað um. Баð á ekki síst við um viðhorf korsaranna sjálfra.

Siðbreytingin mikla hafði átt sér stað fyrir prem aldarfjórðungum pegar Tyrkjaránið reið yfir og lúthersk kenning og siðir höfðu áhrif á viðbrögð og skilning manna á „Tyrkjahættunni“. Af peim ástæðum verður byrjað á pví að kanna viðhorf Marteins Lúthers til Tyrkja, bæði í merkingunni „stjórnendur og pegnar Tyrkjaveldis“ og í merkingunni „,pau sem aðhyllast trúarkenningu Tyrkja, pau sem eru múslímar“ (að nútímaorðalagi).

Tyrkjaránið var ofbeldisaðgerð og má kalla pað hernað ef ákveðnir mælikvarðar eru hafðir um hönd. Hér verður kannað hvaða áhrif pað hafði á pað hvernig samtímamenn upplifðu atburðina og fjölluðu um pá að vígamennirnir komu frá löndum Tyrkja. Í framhaldi af pví er rannsakað hvaða skilning hin herteknu lögðu í prælahaldið sem varð hlutskipti peirra og hvaða tengingu pað hafði við trúarbrögðin.

Herteknir Íslendingar höfðu meðtekið andúð í garð Tyrkja og Tyrkir af holdi og blóði höfðu svipt pau frelsi sínu, landi og ástvinum. Pegar fólkið kom til NorðurAfríku reyndi pað á eigin skinni hvernig nýr „lífheimur“ opnaðist pví, staðfesti sumar hugmyndir pess en ögraði öðrum. Eftir fáanlegum heimildum er reynt að rýna í viðbrögð hinna herteknu, allt frá virkri andspyrnu til pess að ganga til liðs við nýja samfélagið. Rannsakað er hvernig trúskipti komu til og hvaða áhrif pau gátu haft á líf einstaklinganna. Ferill og aðstæður eins trúskiptings, Önnu Jasparsdóttur frá Vestmannaeyjum, eru könnuð og metið hvort hún hafi valið „góða hlutskiptið“.

Dó að áherslan í greininni sé á trúarlega afstöðu og tilfinningu einstaklinga verður hér einnig kannað hvað trúarviðhorfin vógu pungt í viðbrögðum konungsvaldsins við Tyrkjaráninu og hvernig stjórnmál og trú tengdust. Par er raunar einnig um einstakling að ræða: sá var Kristján konungur IV, sem hafði sterka trúarlega afstöðu.

\footnotetext{
${ }^{2}$ John Williams, „The Blame Game: Karen Armstrong Talks About 'Fields of Blood““, New York Times, ArtsBeat, 26. des. 2014, sótt 16. apríl 2021 af https://artsbeat.blogs.nytimes.com/2014/12/26/the-blame-game-karen-armstrong-talksabout-fields-of-blood/.
} 
Að lokum er pess freistað аð „rannsaka hjörtun og nýrun“ 1 peirri von að nema grundvallarskilning manna á peim atburðum sem umturnuðu lífi fjölda fólks. Par er kannað hvaða hjálp kristin trú hafði par að veita.

\section{Kristni og íslam}

Sextánda og sautjánda öld voru átakatímar trúarbragða. Fjölmennu eingyðistrúarbrögðin, kristni og íslam, mættust í austurhluta Evrópu en einkum pó við Miðjarðarhafið. Par tókust á öflugustu veldi pessara trúarheilda, Tyrkjaveldi Ósmana og Habsborgaraheimsveldið með miðstöð á Spáni. Kristnin og íslam voru hins vegar ekki heil og óskipt. Tyrkir voru sunnítar og áttu jafnan í átökum við sjíta í Persíu sem játuðust undir aðra tegund af arfi Múhameðs. Kristnin í vesturhluta Evrópu klofnaði á sextándu öld og kapólskir og mótmælendur tókust á, oft og víða, fram um miðja sautjándu öld.

Petta voru siðskiptatímar og hin evangelíska kirkja var að marka braut sína. Í pví verki purfti að taka afstöðu til hins vaxandi Tyrkjaveldis og trúarkenningar Múhameðs. Marteinn Lúther fjallaði talsvert um Tyrki og íslam í ræðum og riti, stóð fyrir pýðingu á Kóraninum til að hann gæti áttað sig betur á trúarkenningum íslams og andmælti peim í sérstökum ritum. ${ }^{3}$ Petta var kenningastríð og tilheyrði hinu andlega ríki í tveggja ríkja kenningu Lúthers. Lúther talaði hins vegar gegn (nýrri) krossferðá hendur Tyrkjum og pótti mikilvægara að styrkja innviði sannrar kristni og stofna skóla í bæjum pýsku landanna, eins og fram kemur um nauðsyn pess í riti hans:

Og gæfu menn eitt gyllini til pess að berjast gegn Tyrkjum, ef peir væru á hælunum á okkur, væri pað gott og rétt að hundrað gyllini væru látin í té til pess að leggja til fræðslu eins drengs svo að hann yrði sannur kristinn maður. ${ }^{4}$

Í riti skrifuðu 1528 telur hann að „Tyrkir og hvers kyns villukennendur“ eigi heima í hópi hins andkristilega veldis en „pá jafnast peir ekki við páfadóm“. ${ }^{5}$ Árið eftir var hins vegar svo komið að Tyrkir sátu um Vínarborg pó að peir ynnu hana ekki og yrðu að lokum frá að hverfa. Tyrkjaveldi hafði orðið æ stærra í sniðum í hinu veraldlega ríki, einkum á dögum Suleimans mikla soldáns. Veldið var pannig farið að ógna pýsku ríkjunum og pá hvatti Lúther til varnarbaráttu veraldlegra yfirvalda gegn pessari ógn. ${ }^{6}$ Petta taldi hann hlutverk hins veraldlega ríkis en á trúarlega sviðinu var páfadómur áfram talinn verri en Tyrkir. Đó að Tyrkir teljist til óvina, ritar Lúther, setji peir sig ekki ofar guði og leyfi „hverjum sem pað vill að taka kristna trú en krefjast aðeins skatts af peim og borgaralegrar hlýðni."

Í pessu ljósi parf að sjá barnasálminn sem sunginn var í kirkjum lútherstrúarmanna og Lúther samdi 1541 pegar Tyrkir voru komnir inn í Ungverjaland og borgin Buda féll í hendur peim. ${ }^{8}$ Á Íslandi var hann prentaður í sálmabókum allt frá árinu 1555 og langt fram á átjándu öld, ásamt öðrum sálmi gegn Tyrkjahættunni.

\footnotetext{
3 Johannes Ehmann, Luther, Türken und Islam: Eine Untersuchung zum Türken- und Islambild Martin Luthers (1515-1546), Heidelberg: Güntersloher Verlagshaus, 2015.

${ }^{4}$ Marteinn Lúther, Sendibréf til borgarrádsmanna um stofnun og rekstur skóla, í: Marteinn Lúther: Úrval rita 2, 1524-1545, pýð. Gunnar Kristjánsson, ritstj. Arnfríður Guðmundsdóttir, Gunnar J. Gunnarsson og Sigurjón Árni Eyjólfsson, Reykjavík: Nefnd um fimm alda minningu siðbótarinnar og Skálholtsútgáfan, 2018, bls. 29-58, hér 33.

5 Sama rit, bls. 133.

${ }^{6}$ Sama rit, bls. 235

7 Sama rit, bls. 350.

8 Ehmann, Luther, Türken und Islam, bls. 415-416.
} 
Halt oss, Guð, við pitt hreina orð

og heft páfans og Tyrkja morð,

sem vilja Krist vort sérlegt skjól

setja af sínum veldisstól. ${ }^{9}$

คó að Lúther setji páfann og Tyrkjann undir sama hatt í pessum barnasálmi leit Lúther að jafnaði á páfavaldið sem hina innri hættu en Tyrkjaveldi sem hina ytri ógn pó að hann andmælti einnig íslamskri trúarkenningu.

рað birtist í skýru ljósi eftir Tyrkjaránið að konungsvaldið var yfir kirkjuna sett í veraldlegum efnum á Íslandi. Konungsvald og kirkja voru pó engan veginn aðskilin heldur áttu pessi tvö valdsvið að vinna saman að sama markmiði og pað markmið var sannarlega kristilegt og trúarlegt. Hjalti Hugason orðaði pað svo „að fram kom ríkiskirkja og jafnvel ríkisátrúnaður par sem kirkja og ríki eru algerlega samfléttuð.“10 Hjalti álítur að pessi próun hafi verið almenn um Evrópu, óháð tveggja ríkja kenningu Lúthers sem hafi haft lítil áhrif á Íslandi. ${ }^{11}$ Hið veraldlega konungsvald var hins vegar harla fjarlægt á Íslandi og pví reyndi oft á viðbrögð kirkjunnar manna, t.d. pegar söfnun fyrir útlausn fanga frá Norður-Afríku stóð fyrir dyrum. Kirkjunnar mönnum rann einnig blóðið til skyldunnar par sem um sálarheill hinna herteknu var að tefla.

Degar Lúther talaði um Tyrki átti hann annars vegar við Tyrkjaveldi Ósmana sem veraldarvald og hins vegar við handhafa kenningar Múhameðs spámanns, p.e. sem múslíma (pó að pað hugtak væri ekki notað). Alsír játaðist undir Tyrkjaveldi 1517, á ævitíma Lúthers, en ekki er vitað til pess að hann hafi nefnt pað landsvæði á nafn eða korsarana sem herjuðu á Miðjarðarhafinu, stundum framan af í beinni pjónustu við höfuðstöðvarnar í Konstantínópel (Istanbul). Tyrkjaheitið breiddist út og var notað almennt yfir alla sem aðhylltust kenningu Múhameðs, jafnvel í Marokkó, sem laut pó ekki Tyrkjasoldán. Ekki er vitað hvenær íslenskir höfundar tileinkuðu sér petta útvíkkaða heiti. Nefna má pó að í bænabók Guðbrands biskups, sem fyrst var prentuð á Hólum 1607, er ein bæn „, móti Tyrkjanum og hans týrönnum“ par sem beðið er um „hjálp og styrk á móti peim grimma týranna og alls kristindóms höfuðóvin Tyrkjanum og ödrum hans mökum " [mín leturbreyting]. ${ }^{12}$ Algeirsborg mátti kalla maka Tyrkjans.

Magnús Pétursson, sem síðar varð prófastur Skaftafellspings, sendi bæði sjóræningjum frá Alsír (Asser) og Dúnkerk (flæmska Duunkerke, franska Dunkerque) sóninn „staddur á Hörgslandsfjöru á Síðu við Skaftárósa“. Algeirsborg var miðstöð Tyrkja, Dúnkerk útvörður kapólska Spánarveldisins.

$$
\begin{aligned}
& \text { Assers innbyggendum } \\
& \text { og peim Duncarkuendum } \\
& \text { pessi són sé sendur ... }
\end{aligned}
$$

Frá báðum pessum stöðum, Algeirsborg og Dúnkerk, höfðu korsarar (fríbýtarar, sjóræningjar með leyfisbréf) herjað á Íslandsstrendur. ${ }^{14}$ Forystumenn siðbótarinnar

\footnotetext{
9 Jón Porkelsson, „Formáli“, Tyrkjaránið á Íslandi 1627, ritstj. Jón Porkelsson, Reykjavík: Sögufélag, 1906-1909, bls. IXLVI, hér XVI-XVIII.

${ }^{10}$ Hjalti Hugason, „Áhrif siðbótarinnar á Íslandi: Tilraun til jafnvægisstillingar — Ś̉ðari grein“, Ritið 2/2019, bls. 209-247, hér 224.

${ }^{11}$ Sama rit, bls. 225.

12 Jón Porkelsson, „Formáli“, bls. XIV.

${ }^{13}$ Magnús Pétursson, „Tyrkjasvæfa“, Tyrkjaránið á Íslandi 1627, bls. 515-523, hér 515 og 519.

${ }^{14}$ Helgi borláksson, Sjórán og siglingar: Ensk-islensk samskipti 1580-1630, Reykjavík: Mál og menning, 1999, bls. 211 o.v.
} 
á Íslandi gerðu sér pannig grein fyrir andstæðingum lútherskrar kenningar og kirkju. Pannig biður Sveinn Símonarson, prestur í Holti i Önundarfirði, faðir Brynjólfs biskups, svo í hugvekjum sínum: „Afstýr Tyrkjans grimmdarsverði, Antakristsins [páfans] oki, Kalvinistanna svikum."15

Lærðum mönnum á Íslandi var fullljóst að í Tyrkjaráninu var ekki einungis um að ræða sjóræningja og mannræningja heldur trúarlega andstæðinga kristninnar. Um pað var hægt að lesa í ritum sem bárust til landsins og petta var vafalaust kennt í skólum í Danmörku sem peir sóttu. Ætla má að almenningur sem tók undir sálma og heyrði predikanir í kirkjum hafi einnig meðtekið pennan boðskap.

\section{Trúarsiðir}

Hafi herteknir Íslendingar verið í trúarháska í landi Tyrkja (p.e. múslíma) mætti ætla að skýrt væri í hverju hann fælist, hver munurinn væri á kenningu Krists og Múhameðs. Á petta er pó sjaldan minnst í frásögnum og bréfum peirra sem fjölluðu um Tyrkjaránið í samtímanum. Talsvert er af stóryrðum, t.d. pegar íslensku fangarnir skrifa 1635 að peir pjáist „undir kapteinaflaggi og fánum pess mikla sjökórónaða dreka Mahomets." "16 Detta er að vísu ekki einungis stóryrði heldur vísun í 13. kafla Opinberunarbókar Jóhannesar par sem Lúther túlkaði drekann (dýrið) sem táknmynd páfadóms, keisarans og Tyrkjans. Hér er pýðingin á orðum Lúthers færð til nútímastafsetningar.

Hér útsteypist og hellist nú í einu öll djöfulsins síðasta grimmdar reiði til samans par í austurálfu heimsins, pað annað vei, Mahometh og Saraceni [Serkir], hér í vesturálfunni páfadómurinn og keisaradómurinn með pví priðja vei. ${ }^{17}$

Detta er prentað í formála Lúthers í Guðbrandsbiblíu 1584 og nær samhljóða í Porláksbiblíu 1644. Lykill Lúthers að skilningi á Opinberunarbókinni var framsókn Tyrkja í Evrópu og sá skilningur kom fram í formálum hans sem voru prentaðir í íslenskum biblíuútgáfum og var pví kunnur peim sem vel lásu, eins og síðar verður vikið að.

Ólafur Egilsson lýsir pví í ferðasögu sinni að eftir hálfs mánaðar siglingu með fangaskipinu hafi skollið á „stór stormur af landnyrðingi svo lá við töpun“ og Tyrkirnir hafi orðið óttaslegnir og fórnuðu feitum hrút ,,annaðhvort djöflinum eða einhverjum sínum afguði“. ${ }^{18}$ Líklega fer Ólafur með rétt mál hér pví að mjög svipuðum sið og í sama tilgangi lýsti herleiddur Portúgali, João Mascarenhas, sex árum fyrr pegar hann var fluttur á skipi um Gíbraltarsund sem jafnan var varasamt. ${ }^{19}$ Dýrafórnir hurfu nokkuð snemma í kristnum sið en hér má engu að síður bekkja vísun í söguna af Abraham sem ætlaði að fórna syni sínum að boði guðs sem stöðvaði hann pó er til verksins átti að koma pví að hann hefði pegar sýnt vilja sinn. Pessi saga er, með vissum tilbrigðum, í megintrúarritum „abrahamísku“ trúarbragðanna, kristni,

\footnotetext{
15 Jón Porkelsson, „Formáli“, bls. XV.

${ }^{16}$ Bréf fanganna úr Algeirsborg, Tyrkjaránið á Íslandi 1627, bls. 423-428, hér 425.

${ }^{17}$ [Marteinn Lúther], ,Formale yfer S Johannis Opinberaner“", Biblia: Dad Er Øll Heilóg Ritning utlógd a Norranu — Med Formalum Doct. Martini Lutheri, Nyia Testamentum a Norranu, Hólum: 1584, bls. CXVr.

18 Ólafur Egilsson, „Ferðasaga síra Ólafs Egilssonar“, B-gerð, Tyrkjaránið á Íslandi 1627, bls. 135-203, hér 152-153.

${ }^{19}$ João Mascarenhas, Esclave à Alger: Récit de captivité de João Mascarenhas (1621-1626), ritstj. og pýð. (úr portúgölsku) Paul Teyssier, París: Chandeigne, 1993, bls. 53.
} 
íslam og gyðingdómi. Kóraninn mælir ekki fyrir um að líkja eftir pessari fórn en dýrafórn af pessu tagi er pó sums staðar iðkuð allt til pessa dags í íslömskum sið. ${ }^{20}$

Ólafur lýsir pví einnig í ferðasögu sinni að maður einn á skipinu hafi pvegið sig í vatni hvað eftir annað og aðrir hafi pvegið honum allan pann mánuð sem pau voru á siglingu. Margrét, kona sr. Jóns borsteinssonar, sem veginn var í Vestmannaeyjum, sagði að petta hefði verið banamaður Jóns. „Đessi hans hreinsan kann hann ekki hreinan að gera pó hann héldi sig eftir peim Moses setningum að pvo klæðin og baða í vatni“" ritar Ólafur. ${ }^{21}$ Pessa útleggingu — og fleiri trúarlegar hugleiðingar — er ekki að finna nema í einni afskrift af sögu Ólafs. Frumrit sögunnar er ekki lengur til en dr. Jón Porkelsson áleit petta tiltekna afrit, skrifað 1741, vera næst frumritinu pegar hann bar saman öll tiltæk handrit og birti á prenti 1906-1909.22 Formáli Ólafs og tveir inngangskaflar hafa alls staðar verið hreinsaðir burt en par var hið guðfræðilega samhengi atburðanna sett fram, einkum „hvernig guð hafi í pví gamla og nýja testamentinu látið áminningar undan fara áður straffið komið hefur." Dessari stuttu endursögn er haldið til haga í afskriftinni frá $1741 .{ }^{23}$ Í frásögninni af handapvotti skipverjans kemur fram að Ólafur veit að vatnspvotturinn hefur trúarlega merkingu; að Móses fékk fyrirmæli um að útbúa ker fyrir lýðinn að pvo sér áður en farið væri til helgiathafna (1Mós 30.7-21) og raunar er miklu víðar minnst á hreinsunarmátt vatnsins í Biblíunni. Hvort sem Ólafur gerði sér grein fyrir að „setning“ (kenning) Móses á sér einnig hliðstæðu í Kóraninum pá skynjaði hann trúarlegt inntak hennar. Vatnspvottur á líkamspörtum til hreinsunar er altíður í trúarsiðum pó að lítið væri eftir af vatni í kristnum sið á dögum Ólafs annað en í skírninni.

Ólafur Egilsson greinir siði múslíma, sér viss líkindi með kristnum venjum eða finnur peim stað í Ritningunni en lýsir andúð sinni. Hann er meðvitaður um sinn lútherska sið og lýsir skrautlegum og margbrotnum háttum kapólskra í ítölsku borginni Livorno „ei til lærdóms heldur til aðhláturs að peirra apaspili“" og á pá sérstaklega við vitjun til sjúkra. Mikill mannfjöldi fylgdi munki til dyra hjá sjúklingi og hélt yfir honum silkitjaldi en munkurinn hefur „tösku á hálsinum og kórbjöllukorn sem jafnan hringist". Síðan gerir Ólafur greinarmun á svartmunkum, grámunkum og hvítmunkum og segir að peir láti raka sig og klippa á fjórtán daga fresti. „En pó peir pvægju sig með lút og tækju par með til mikla sápu pá birtist pó pess meir peirra ódyggðir.“24 Ólafur er hollur sinni lúthersku pó að hann hafi auga fyrir siðum annarra eins og nánar verður vikið að síðar.

\footnotetext{
${ }^{20}$ Mustafa Akyol, „Why Do Muslims Slaughter Animals for God?““ New York Times, 21.8.2018, sótt 16. apríl 2021 af https://www.nytimes.com/2018/08/21/opinion/eid-al-adha-sacrifice-isaac.html. Sjá einnig t.d. Yvonne Sherwood, „Binding-Unbinding: Divided Responses of Judaism, Christianity, and Islam to the "Sacrifice” of Abraham's Beloved Son", Journal of the American Academy of Religion 74/2004; Daniel C. Ullucci, The Christian Rejection of Animal Sacrifice, Oxford: Oxford University Press, 2012

${ }^{21}$ Ólafur Egilsson, „Ferðasaga síra Ólafs Egilssonar“, bls. 152.

22 Sama rit, bls. 135-137.

${ }^{23}$ Sama rit, bls. 139.

${ }^{24}$ Sama rit, bls. $172-174$.
} 


\section{Hernaður}

Tyrkjaránið var hernaðaraðgerð af sérstöku tagi. Fernand Braudel kallaði sjórán „staðgengil stríðs“ og „óyfirlýsta stríðið“ í hinu áhrifamikla riti sínu um Miðjarðarhafið á dögum Filipusar II. ${ }^{25}$ Áhlaup, hertaka og rán af hafi voru skilgreind í alpjóðarétti og samningum allt fram á nítjándu öld ýmist sem lögmætur stríðsgjörningur eða glæpsamleg sjórán en hér verður ekki farið nánar út í pá sálma en vísað í önnur rit. ${ }^{26}$ Markmiðið með hernaðarárásum múslíma á borð við Tyrkjaránið var ekki að vinna land eða fella sem flest af fólki heldur að ná fólkinu lifandi og heimta lausnargjald fyrir pað. Korsararnir í Norður-Afríku voru ekki einir um petta pví að kristnir korsarar á Möltu gerðu pað sama pó að peir væru ekki eins stórtækir. Evrópumenn voru einnig á tímum Tyrkjaránsins að hefja stórfellda herleiðingu fólks yfir Atlantshafið frá Afríku en peir létu yfirleitt aðra um að hertaka pað og koma pví til strandar. Á galeiðum Frakkakonungs og ítalskra borgríkja reru prælar frá löndum múslíma fram eftir átjándu öld.

Sautjánda öldin var hernaðaröld og lágu kristnir síst á liði sínu í peim efnum. Raunar var allur heimurinn undirlagður, segir sagnfræðingurinn Geoffrey Parker, „more wars took place around the world than in any other era before the Second World War. “27 Fræðimenn ræddu um stríð, réttmæti stríðs (lat. justum bellum) og hvað réttmætt væri að gera í stríði (lat. justum in bello), jafnvel um heilagt stríð. Nokkrir virtir evrópskir fræðimenn á borð við Spánverjann Franciscus de Vitoria og Hollendinginn Hugo Grotius töldu trúarbrögð ekki lengur fullnægjandi ástæðu stríðs ein og sér eins og verið hafði í krossferðunum. Hollenska (kalvíníska) fræðimenn greindi bó á um hlut trúarinnar í réttlætingu stríðs. ${ }^{28}$ Lúther talaði gegn slíku stríði pegar raddir heyrðust um að nú væri rétt að efna til krossferðar gegn Tyrkjum. ${ }^{29}$ Um heilagt stríð, jihad, var einnig rætt í íslamska heiminum og var margs konar skilningur á lofti um pað, misjafnlega herskár. Í stórum dráttum má segja að íslömsk stjórnvöld í borgum Norður-Afríku lytu sömu meginreglum og Evrópuríkin: stríð var háð gegn lögmætum óvinum sem gátu orðið lögmætir vinir með samningum. Spánn var hinn eilífi óvinur, af trúarástæðum en ekki síður vegna silfursjóðanna sem fluttir voru frá Suður-Ameríku og stórveldisstöðu landsins sem hafði auk pess hrakið Mára í hundruðum púsunda úr landi en margir peirra höfðu leitað skjóls í Algeirsborg og Salé og hugðu á hefndir. Hefnd var að vísu ekki lögmæt stríðsástæða en til var hugtakið postliminum sem, allt frá dögum Rómverja, taldist veita réttmæta ástæðu til að endurheimta pað sem tekið hafði verið með ólögmætum hætti. Annað mál er pað að Ísland — og Danaveldi — hafði ekki hrifsað neitt frá Norður-Afríku á pessum tíma og var ekki í óvinahópi (og ekki í vinahópi heldur). Herferð til Íslands var pví varla réttlætanleg.

Með góðum rökum má fullyrða að Tyrkjaránið sé eina hernaðarárásin sem Íslendingar hafa orðið fyrir. Breski flotinn hertók að vísu Ísland árið 1940 en pað var gert

${ }^{25}$ Fernand Braudel, The Mediterranean and the Mediterranean World in the Age of Pbilip II 2, pýð. Siân Reynolds, London: Fontana Press, 1987, bls. 865.

${ }^{26}$ Porsteinn Helgason, Minning og saga í jósi Tyrkjaránsins, Reykjavík: Hugvísindastofnun, 2013, bls. 246-276.

${ }_{27}$ Geoffrey Parker, Global Crisis: War, Climate Change and Catastrophe in the Seventeenth Century, New Haven \& London: Yale University Press, 2013, bls. 26.

${ }^{28}$ Joris van Eijnatten, „Religionis Causa: Moral Theology and the Concept of Holy War in the Dutch Republic“, Journal of Religious Ethics, 4/2006, bls. 609-635.

${ }^{29}$ Martin Luther, „Vom Kriege Wider die Türken“, Martin Luther, Der Christ in der Welt, Luther Deutsch: Die Werke Martin Luthers in neuer Auswahl für die Gegenwart, Stuttgart: Ehrenfried Klotz Verlag, 1967, bls. 94-118. 
með óformlegu sampykki íslenskra stjórnvalda. Íslendingar höfðu lítið til að bera saman við pó að peir vissu mæta vel af átökum í prjátíu ára stríðinu á sama tíma og pess vegna gat Bjarni Gissurarson í Pingmúla ort:

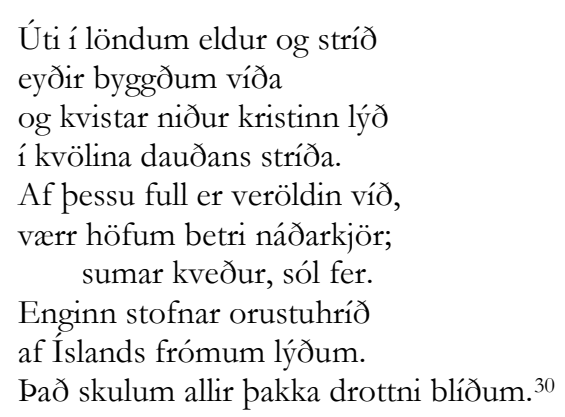

En voru korsararnir í Algeirsborg (og Salé) herskárri en aðrir og mátti rekja hernað peirra til trúarbragða? Jónas Jónsson frá Hriflu var ekki í vafa um svarið við pessu í kennslubók sinni fyrir barnafræðsluna frá 1916: „Đjóðin var Múhameðstrúar, grimmlynd mjög og herská.“31 Parna endurspeglar Jónas viðhorf sem voru landlæg í Evrópu.

Kláus Eyjólfsson, sem manna fyrstur skráði frásögn af Tyrkjaráninu, var viss um stærðargráðu ofbeldisins (samkvæmt afskrift frá 1741):

... pví ég meina ei muni slíkt heyrst hafa, hvorki utan lands né innan, að með meinlaust fólk hafi svo
grimmilega höndlað verið, hvar ei finnast dæmi til, og varla í Jerúsalems eyðileggingu. ${ }^{32}$

Kláus hafði að vísu ekki margt til að bera saman við af eigin raun. Hann hafði sjálfsagt vitneskju, jafnvel beina, af yfirgangi enskra sjóræningja í Vestmannaeyjum árið 1615 sem gengu par berserksgang í nokkra daga en drápu pó ekki fólk. Vafalaust hefur hann einnig heyrt um víg Baskanna á Vestfjörðum um svipað leyti pó að við vitum ekki hve nákvæma vitneskju hann hafði af aðförum Vestfirðinga.

Í venjulegum hernaði er markmiðið að gera hermenn óvíga — og óbreyttir borgarar hljóta óhjákvæmilega sömu örlög — og að ná landsvæðum og verðmætum. Fangar eru teknir og peirra bíða yfirleitt kröpp kjör uns friðarsamningar nást með fangaskiptum og sumir kunna að vera keyptir út. Í herferðum korsara sem um ræðir í Tyrkjaráninu og meðal annarra svipaðra aðila við Miðjarðarhafið voru markmiðin önnur, sem sé að ná fólki lifandi og við sem besta heilsu. Pess vegna forðuðust korsararnir vopnuð átök og vildu helst koma fólki að óvörum, króa pað af og handsama. Petta tókst að mestu í Grindavík og á Djúpavogi (og ekki síður í Baltimore á Írlandi árið 1631 pegar korsarar umkringdu rúmlega hundrað manna porp pegar allir voru 1 fasta svefni). ${ }^{33}$ En petta tókst ekki í Berufirði og alls ekki í Vestmannaeyjum. Dá var fólk höggvið til bana og limlest. En tölurnar segja engu að síður sína sögu pví að sögumenn tóku pær saman. Í Tyrkjaráninu voru a.m.k. 382 einstaklingar herteknir lifandi og fluttir úr landi en 45 drepnir. Hlutfallið er einn á móti 8,5. Til samanburðar má taka umsátrið í Magdeborg í Pýskalandi árið 1631. Pegar keisaraherinn braust gegnum varnir borgarinnar hófst mikið blóðbað og borgin stóð í ljósum logum. Giskað er á að 20 púsund manns hafi farist og nokkur púsund sloppið lifandi. par var um reglulegan hernað að ræða par sem kristnir réðust á kristna, kapólskir á

\footnotetext{
${ }^{30}$ Bjarni Gissurarson, Sólarsýn, ritstj. Jón M. Samsonarson, Reykjavík: Menningarsjóður, 1960, bls. 20.

31 Jónas Jónsson, Íslandssaga 3, Reykjavík: Ríkisútgáfa námsbóka, [án árs], bls. 13.

32 Kláus Eyjólfsson, „Frásögn Kláusar lögréttumanns Eyjólfssonar“", Tyrkjaránið á Íslandi 1627, bls. 18-90, hér 73.

${ }^{33}$ Des Ekin, The Stolen Village: Baltimore and the Barbary Pirates, Dublin: The O’Brien Press, 2008.
} 
mótmælendur. Séra Guðmundur Erlendsson í Felli í Skagafirði orti um báða atburðina, Tyrkjaránið og eyðingu Magdeborgar, og fordæmingin á vígamönnum er ótvíræð í báðum tilvikum. ${ }^{34}$

\section{Drælahald}

Herleiddu Íslendingarnir árið 1627 pekktu ekki prælahald af eigin raun fyrr en peir voru seldir á markaði í Norður-Afríku. Fyrir peim hefur prælahald verið „tyrkneskt“ fyrirbæri. Kannski hefur einhver peirra lesið rit (sem varðveitt er í afriti frá 1787) og nefnist „Hvernig Tyrkir kaupa kristnar manneskjur og hverja eymd og plágu pær af peim líða.“"35

prælar voru löngu horfnir á Íslandi og víðast um Evrópu. „Hver sá maður sem stigið hefur fæti í konungsdæminu er frjáls“ lýsti sjávarmálaráðherra Frakklands yfir árið 1694 en bætti við: „Ekki má víkja frá pessum lögum nema í tilviki Tyrkja og Mára sem eru sendir til Marseille til að pjóna á galeiðunum pví áður en peir koma pangað hafa peir verið keyptir erlendis par sem pess konar verslun er viðurkennd.“36 Kristnir menn mega ekki prælka aðra kristna pótt í hernaði sé en í réttmætu stríði mátti hins vegar hneppa trúleysingja (les: múslíma) í prældóm. Betta var úrskurður dómara í Sorbonne fjórum árum síðar. Đó að kristnir mættu ekki prælka kristna mismunaði franska konungsvaldið kristnum trúfélögum pegar kom að pví að losa fólk úr prælahaldi og kaupa föngum frelsi í Norður-Afríku. Kapólskir voru endurleystir, mótmælendur, húgenottarnir, voru skildir eftir. ${ }^{37}$

Dau sem sóttust eftir frelsi og endurlausn gátu átt præla og sáu enga mótsögn í pví. Sagnfræðingurinn Natalie Zemon Davis lýsir góðu dæmi um pessi viðhorf. Đað fjallar um gyðinga sem tóku sig upp frá Hollandi í byrjun sautjándu aldar og settust að í norðurhluta Brasilíu sem Hollendingar höfðu numið. Petta var eins konar exodus peirra til frelsisins í minningu flóttans frá Egyptalandi forðum. Ættin Nassy, sem Zemon Davis fjallar um sérstaklega, var upprunnin í Portúgal par sem pau höfðu orðið að kasta trú sinni og taka kristni. Nú skyldu pau blómstra frjáls í sínum gyðingdómi á nýjum stað. Samtímis keyptu pau sér afríska præla pegar peir voru á boðstólum í nýlendunni til að vinna á sykurekrum sínum. Karlmönnunum meðal gyðinganna pótti ekki verra að komast að pví að prælarnir frá Angóla og Gíneuflóa voru umskornir rétt eins og peir. David Nassy flutti að vísu aftur til Amsterdam en var áfram umhugað um nýlendur og athvarf fyrir gyðinga. Í Amsterdam tók hann að vinna með hinum víðkunna kortagerðarmanni og útgefanda Juan Blaeu og pýddi fyrsta bindi af Grand Atlas á spænsku. Hann bætti par ýmsu við, t.d. um landnám Íslands, sem hann dáðist mjög að par sem landnámsmenn hefðu byggt porp en ekki hávaðasöm spillingarbæli sem borgir væru — og sá par líklega fyrirmynd fyrir gyðingabyggðirnar í Ameríku. Nassy las sér einnig til um illa meðferðá frumbyggjum Grænlands pegar tólf peirra voru teknir og fluttir til Kaupmannahafnar 1605 og 1606

\footnotetext{
34 Dórunn Sigurðardóttir og Porsteinn Helgason, „Hvaða sögum fór af eyðingu Magdeborgar í Skagafirði?“, Nýtt Helgakver: Rit til heiðurs Helga Skúla Kjartanssyni sjötugum 1. febrúar 2019, bls. 103-118; Guðmundur Erlendsson, „Ræningjarímur“, Tyrkjaránid á Íslandi 1627, bls. 465-496.

35 Jón Porkelsson, „Formáli“, bls. XXIII.

36 Gillian Weiss, Captives and Corsairs: France and Slavery in the Early Modern Mediterranean, Stanford: Stanford University Press, 2011, bls. 91. Dýðingin er höfundarins (DH) eftir pýðingu Gillian Weiss úr frönsku.

37 Sama rit, bls. 91.
} 
með hörmulegum afleiðingum. „Harðneskjulegt framferði,“ skrifar David Nassy. „Hvílík mannvonska ... Hvílík ruddamennska stórveldis.“ Og hann ímyndar sér pann hrylling að vera frjáls að uppruna en tekin til fanga og jafnvel prælkuð og send í útlegð frá sínu eigin landi. ${ }^{38}$ Natalie Zemon Davis bætir við: „He did not apply to his own 1657 contract to bring several hundred African slaves to the new Essequibo River colony the judgment of "execrable inhumanity" that he made of the Danish kidnappers. “39

David Nassy og landar hans sáu greinilega enga pverstæðu í pví að gyðingar berðust fyrir frelsi sínu og að hann hefði mikla samúð með Grænlendingum sem voru sviptir frelsi sínu en vera samtímis með 1158 afríska præla í eigu sinni pegar peir höfðu sest að í Súrínam í Suður-Ameríku með stuðningi hollenskra yfirvalda.

Ólafur Egilsson stóð frammi fyrir ákveðinni pverstæðu pegar honum var sleppt frá Algeirsborg par sem landar hans, hinir kristnu Vestmannaeyingar, höfðu verið seldir á prælamarkaði „,svo sem annar fénaður“.40 Degar hann kom til borgarinnar Livorno á Ítalíu sá hann „par pað meistaraverk sem ég sá hvergi slíkt hvað að voru iiij mannsmyndir steyptar af eiri ... Pær myndir voru í fjötrum af eiri ... eftirmynd eins Tyrkja og hans sona“. Parna var tilverunni snúið við frá Algeirsborg: Hin kristnu höfðu fjötrað Tyrkina. Ólafur verður hugsi og leitar réttlætingar: Dessir höfðu „kristninni ... stóran skaða gert.“ Og kaflann endar hann eins og jafnan í pessu (líklega) upprunalegasta afriti af sögu hans á biblíustað: „Nú hljóðar ritningin að ólukkan sú komi yfir pá óguðlegu sem peir fyrirbúa peim. “41

Abrahamísku trúarbrögðin kristni, íslam og gyðingdómur réttlættu öll prælahald í ritum sínum. Lagaspeki sautjándu aldar var af pessu tagi: Drælahald var leyfilegt ef „,rétta“ fólkið var prælkað. Íslendingarnir komust að pví að prælkun peirra hafði pá björgunarglufu að mögulegt var að endurleysa pá með fé, hin herteknu voru í „endurlausnarprælkun“ (e. ransom slavery). Slíkt bauðst ekki peim afrísku prælum sem Evrópumenn fluttu yfir Atlantshafið og prælkuðu í Ameríku.

\section{Lífheimurinn}

Kenningar og hugmyndafræði hafa sín áhrif en pegar á hólminn er komið tekur lífheimurinn (b. Lebenswelt) við eins og fyrirbærafræðingar kalla hann, „einfaldlega sá heimur sem við lifum og hrærumst í, sá hversdagslegi heimur sem við eigum, svo að segja, í stöðugu trúnaðarsambandi við“, ${ }^{42}$ p.e. hin beina reynsla, eins og ofbeldi sem menn standa frammi fyrir en einnig pær bjargir sem peir leita sér og ný tækifæri sem peir ef til vill eygja.

Detta á við um Íslendingana sem stigu á land í Norður-Afríku síðsumars árið 1627. Hin herteknu höfðu verið hrifin á brott frá heimalandinu með ofbeldi og nú voru flest peirra höfð til sýnis á prælamarkaði og seld. Andúðin á trúarbrögðum kenndum

\footnotetext{
${ }^{38}$ Natalie Zemon Davis, „Regaining Jerusalem: Eschatology and Slavery in Jewish Colonization in Seventeeth-Century Suriname", The Cambridge Journal of Postcolonial Literary Inquiry 1/2016, bls. 21.

${ }^{39}$ Sama rit, bls. 22.

40 Ólafur Egilsson, „Ferðasaga síra Ólafs Egilssonar“, bls. 154.

${ }^{41}$ Sama rit, bls. 176.

${ }^{42}$ Björn Porsteinsson, „Hvað er fyrirbærafræði?“, Vísindavefurinn, 2008, https:/ / www.visindavefur.is/svar.php?id=7104; Dan Zahavi, Fyrirbarafradi, Reykjavík: Heimspekistofnun, Háskólaútgáfan, 2008, bls. 35-39.
} 
við Múhameð var peim innprentuð, að minnsta kosti peim sem höfðu tileinkað sér kristilega kenningu pessa tíma, og styrktist ugglaust við pað áfall sem yfir pau dundi.

Guttormur Hallsson, bóndi á Búlandsnesi, getur staðið hér sem fulltrúi pessara Íslendinga, einkum vegna pess að varðveitt er afrit af bréfi sem hann skrifaði í Algeirsborg 1631 til skyldfólks síns og vina á Íslandi. Guttormur var að vísu enginn almúgamaður á pessum tíma pví að bréf hans er með talsverðu mælskulistarskrúði og latínusetningum. Hann formælir Algeirsborg

\footnotetext{
... og svo peirra óguðlegu athæfi sem hér fer fram í pessu syndsamlega líferni í pessum stað pví hér er ei að heyra nema ugg og ótta, nagg og deilur, morð og manndráp dag frá degi, hofmóð, drambsemi og djöfla æði. Рað má reikna að vér séum í jarðneskum helvítis kvölum, úr hverri baráttu oss virðist guð náðarsamlega að hjálpa fyrir sína miklu náð og miskunnsemi. ${ }^{43}$
}

Hér er fordæming með málsnilld og almennum orðum. Pegar kemur að einstökum atvikum og eigin hag verður nokkuð annað hljóð í strokknum. Sjálfur segist hann eiga roskinn mann að húsbónda sem eigi bráðunga konu og fjögur ung börn og „hafa pau bæði mér meinlaus verið“ og einkum konan sem hefur stillt reiði manns síns „fyrir hennar góðar tillögur.“44 Hann viðurkennir ennfremur að fólk eignist mismunandi húsbændur, suma góða en aðra grimma og harða. „Mjög auma og fáheyrða siði hefur petta heiðna og óguðlega fólk, “ skrifar Guttormur og segir ennfremur að petta lýsi sér einkum í „skikkunum, klæðanostri, pvottagangi og tærilæti.“45 Dessu mætti einnig lýsa með nútímalegu orðalagi sem borgaralegu hreinlæti og umgengnisvenjum.

Skyldan tón er að heyra í bréfi Jóns Jónssonar frá Grindavík (sem einnig er undirritað af Helga bróður hans). Jón var lærður maður, eins og Guttormur, og skreytir mál sitt ekki minna. Hann hefur einnig almenn orð um borgina og kveður að par séu „,illræðisvargar, leon og djöfullegt fólk og holdlegir árar.“ Detta er hin almenna lýsing en pegar kemur að einstaklingunum — peim sjálfum, peirra nánustu og jafnvel Íslendingunum yfirleitt — eru árarnir ekki eins voðalegir. Húsbændurnir hafa ekki getað gert peim bræðrum mein né flestum landsmanna peirra, segir Jón. Hann segir frá frænda sínum og nafna sem var í Salé „hjá einum vínberja okurkarli, sem er par með kaupmaður, en Jón sáir og erjar hans víngarð, og pað er sá besti húsbóndi og patron sem hann hefur í peirri borg. “46

Jón segir einnig frá ráðum sem hin herleiddu bræða með sér og hafa notað. Helgi bróðir hans átti í Saléborg grískan trúskipting að húsbónda sem reyndi að koma honum af trúnni með barsmíðum og heitingum par til Helgi hótaði pví að kasta sér af kastalanum í sjóinn eða skera sig til dauðs með hnífi. Við petta breytti húsbóndinn framferði sínu og var meinlaus eftir pað. ${ }^{47}$ Einnig segja bræðurnir í bréfinu að húsbændurnir hafi batnað við pá eftir að peir lærðu tungumálið sem talað er. ${ }^{48}$ Jón veltir flóttaleiðum fyrir sér — eins gerði Guttormur — og segir m.a. að Helgi hafi ráðlagt Héðni bróður sínum að leggja sig eftir siglingum par sem pað væri vísasti vegurinn til að frelsast. ${ }^{49}$

Séra Ólafur Egilsson gerði sér grein fyrir gæðum landsins sem Íslendingarnir voru fluttir nauðungarflutningi til:

\footnotetext{
43 Guttormur Hallsson, bréf frá Algeirsborg 1631, Tyrkjaránið á Íslandi 1627, bls. 386-397, hér 389.

44 Sama rit, bls. 389.

${ }^{45}$ Sama rit, bls. 393.

46 Jón Jónsson, bréf til foreldranna, Tyrkjaránið á Íslandi 1627, bls. 372-384, hér 375.

${ }^{47}$ Sama rit, bls. 376.

48 Sama rit, bls. 373

${ }^{49}$ Sama rit, bls. 375 .
} 
Landið grær tvisvar um árið, og svo vex allur ávöxtur jarðarinnar, korn, vínber, grjón, aldrei gras slegið og aldrei peningur inn í hús látinn pví að par er enginn vetur, aldrei frost né snjór um alla ævi. Og ekki er í gluggunum nema járngrindur. Sauðfé ávaxtast tvisvar um árið, hvert sauðfé bæði er stórt og svo mjög feitt, og ekki er par neinn geldur sauður.

Hvert er réttlæti drottins, að landgæðum er svo misskipt? Ólafur veltir pessu fyrir sér og kemst að pessari niðurstöðu:

Deir meðtaka sitt góða í pessu lífi — máske, — item fegra sig sjálfir sín á milli, svo að peir framkomi sínu vondu málefni sem Davíð segir. En vér erum drottins. ${ }^{50}$

Björn á Skarðsá endursegir hugleiðingar Ólafs og útskýrir nánar (eða hefur eftir upprunatexta Ólafs): „Deir meðtaka hér hið góða en vér vonum eftir eilífu fagnaðarins ríki sem aldrei endar."

Höfundar peirra sendibréfa sem varðveist hafa, Guttormur, Jón frá Grindavík og Guðríður Símonardóttir, héldu trú sinni en víst er hins vegar að margt fólk kastaði kristinni trú sinni og varð eftir í Norður-Afríku. Landið hafði visst aðdráttarafl, eins og sjá má af lýsingum hins rétttrúaða Ólafs Egilssonar, og vera má að fleiri jákvæðar lýsingar og fréttir hafi borist til Íslands. Svo mikið er víst að á Alpingi 1663 var pví hafnað að leggja nýjar álögur á fátækan almúgann í landinu til að kaupa varnarskip pó að hætt væri við nýju Tyrkjaráni par sem almúginn „mætti falla í pá freistni að vera til friðs að vera hertekinn, upp á von og ævintýr. “52 Petta er mælskubragð en pað vísar til einhvers veruleika ef pað á að vera trúverðug rök.

\section{Trúskiptingarnir}

„Hann skrifar að allt pað unga íslenska fólk sé pá turnað en áttatíu lifa alls af pví gamla og miðaldra fólki í pungum pjáningum. “53 Detta hefur Björn á Skarðsá eftir Guttormi Hallssyni í bréfi frá Algeirsborg um 1635. Björn tekur tölur saman í lokin á Tyrkjaránssögu sinni 1643 og telur að 90-100 manns hafi turnast, p.e. tekið íslamska trú. ${ }^{54}$ Í bænaskjali frá 1629, aðeins tveim árum eftir rán, sem skrifað var í nafni 120 Íslendinga og jafnframt sagt að peir hafi verið 380 í upphafi. Í listum sem gerðir voru vegna útkaupaferðar 1635 eru 99 á fyrsta lista, síðan 76 og loks 61. 55 Í seinni útkaupaferð var gerð skrá árið 1644 og á henni eru 14 manns. Hvað varð um fólkið? Allmargt hefur látist af sýkingum sem pað átti ekki ónæmi við. Guttormur og Jón frá Grindavík lýsa pví báðir hve veikir peir urðu fljótlega eftir komuna til NorðurAfríku en báðir náðu sér. Á fimmta tug manna var útleystur með peningum og flest fyrir tilstilli konungs og kirkju og með almennri fjársöfnun. Líklegt er að meira en helmingur Íslendinganna hafi snúist til íslamskrar trúar og orðið pegnar í samfélaginu í Norður-Afríku.

Í samtímaritum, íslenskum jafnt sem erlendum, er oft talað um pvinganir, hótanir og pyntingar sem kristið fólk hafi orðið fyrir til að fá pað til að kasta trú sinni. Pessum lýsingum parf að taka með fyrirvara af tveim ástæðum. Í fyrsta lagi var pað yfirleitt ekki hagur eigendanna að prælar peirra tækju trú heimamanna. Í slíkum tilfellum var

\footnotetext{
50 Ólafur Egilsson, „Ferðasaga síra Ólafs Egilssonar“, bls. 161.

${ }^{51}$ Björn Jónsson, „Tyrkjaránssaga Björns á Skarðsá“, Tyrkjaránið á Íslandi 1627, bls. 204-299, hér 296.

52 Úr bréfabókum Brynjólss biskups Sveinssonar, Safn Fræðafélagsins um Ísland og Íslendinga 12, ritstj. Jón Helgason, Kaupmannahöfn: Hið íslenzka fræðafélag, 1942, bls. 156.

${ }^{53}$ Björn Jónsson, ,Tyrkjaránssaga Björns á Skarðsá“, bls. 294.

${ }^{54}$ Sama rit, bls. 299.

55 „Registur peirra sem ennú lifa í Tyrkeríinu anno 1635“, Tyrkjaránið á Íslandi 1627, bls. 428-431.
} 
nánast útséð um lausnargjald sem var að jafnaði helsta tekjulindin af herleiðingunni. Turnaðir og jafnvel umskornir fangar áttu sjaldan afturkvæmt í kristið land fyrir lausnargjald. Í öðru lagi var pað hagur hinna herleiddu að útmála pann sálarháska sem pau voru í til að vekja samúð og skyldutilfinningu í heimalöndunum. Í pessa veru eru íslensku lýsingarnar á pessum pvingunum til trúskipta: Pær eru almennar og ekki nafngreindar. Pannig talar Jón Jónsson frá Grindavík í bréfi sínu:

Ein stúlka er hér. Undir henni bundinni og klæðflettri hefur eldur kveiktur verið, pó til forgefins.
Sumir hafa á fótum verið upp hengdir til hálfs og með köðlum barðir, og hafa vel varist, svo að margir
hafa vel af komist. Pakkir séu drottni sem dásemdarverkin gerir og lofað sé hans heilaga nafn að eilífu.
Amen. ${ }^{56}$

Næsta setning í bréfi Jóns frá Grindavík er viðurkenning á pví að fleiri séu pó peir sem hafi turnast „og bó komnir til lögaldurs og meir.“57 Í pessu felst ásökun: Vitandi vits hafa margir afneitað trúnni og pvingunarlaust, að pví er skilja má.

Trúskipti gátu bætt hag hinna herleiddu á mörgum sviðum. Pau höfðu pannig meiri möguleika á frelsi par sem Kóraninn talar almennt gegn prælkun trúsystkina. Dau nutu meiri virðingar í samfélaginu og vegur til hagsældar og metorða opnaðist í meira mæli en í kristnum löndum Evrópu par sem ætt og uppruni settu fastari skorður. Félagslegur hreyfanleiki var meiri í korsaraborgunum í Norður-Afríku en í Evrópu. ${ }^{58}$

Íslömsk kenning boðaði að íslam væri náttúrulegt ástand sem börn fæddust til en kristni og gyðingdóm rakti hún til áhrifa frá foreldrunum. Íslam og kristni eiga hins vegar margt sameiginlegt bó að sumt skilji að. ${ }^{59}$ Trúskiptingar purftu pví ekki að kasta öllum fyrri gildum fyrir róða, hvorki hið innra né ytra. Nýjan sið var hægt að taka upp með pví að laga sig að ytri einkennum hans svo að umskiptin gátu orðið býsna yfirborðsleg. Svo lýsir Mári $\left(\right.$ Morisco $\left.^{60}\right)$ nokkur frá Spáni hve íslamskt samfélag tekur vel á móti trúskiptingum og er pá með samanburð í huga við afstöðu spænsks samfélags til Mára sem snerust til kristinnar trúar. Бað nægir að sýna trúrækni á yfirborðinu og taka upp réttan klæðaburð án pess að sálirnar séu skoðaðar nánar, segir í vitnisburði Márans, , við höfum ástæðu til að ætla að flestir peirra séu eins vantrúaðir og peir sem gátu pá af sér."61

Sýndartrúskipti voru alkunn í samskiptum kristni og íslams. Í íslömskum sið, bæði sunníta og sjíta, er orðið taqiyya notað yfir slík trúskipti og pað má útleggja sem „uppgerð í forvarnarskyni“ (e. precautionary dissimulation). Í Kóraninum er gert ráð fyrir pessum möguleika og til er úrskurður (fatwa) frá 1504 sem leyfir múslímum að gera petta í Granada par sem peir stóðu frammi fyrir pví að ekki varð umflúið að kasta trú í orði og athöfnum. Đá væri pað hugarfarið, hinn innri heimur, sem máli skipti. Kjarna íslams gat hinn trúaði geymt í hjarta sér, segir í úrskurðinum, jafnvel pó að hann neyddist til að fara með kristnar bænir, formæla Múhameð spámanni, ákalla

\footnotetext{
56 Jón Jónsson, bréf til foreldranna, bls. 376.

${ }^{57}$ Sama rit, bls. 376.

${ }^{58}$ Ellen G. Friedman, „Christian Captives at "Hard Labor” in Algiers, 16th-18th Centuries“, The International Journal of African Historical Studies 4/1980, bls. 616-632.

${ }^{59}$ Mercedes García-Arenal, „Introduction“, Conversions islamiques: Identités religieuses en Islam méditerranéen/Islamic Conversions: Religious Identities in Mediterranean Islam, ritstj. Mercedes García-Arenal, París: Maisonneuve et Larose, European Science Foundation, 2001, bls. 7-15, hér 9.

${ }^{60}$ Svo voru peir Márar nefndir sem höfðu tekið kristna trú (af heilum eða hálfum hug) og var heitið einkum haft um pá sem reknir voru í útlegð frá Spáni.

${ }^{61}$ Gerard A. Wiegers, „Eurpean converts to Islam in the Maghrib and the polemical writings of the Moriscos“, Conversions islamiques: Identités religieuses en Islam méditerranéen/Islamic Conversions: Religious Identities in Mediterranean Islam, ritstj. Mercedes García-Arenal, París: Maisonneuve et Larose, European Science Foundation, 2001, bls. 207-223, hér 208.
} 
Krist sem son guðs, drekka vín og eta svínakjöt. ${ }^{62}$ Hugsun af pessu tagi, um tvískiptingu líkama og sálar, kemur fram í ferðasögu Ólafs Egilssonar. Degar „kóngurinn“ i Algeirsborg valdi ungan son Ólafs úr hópi hertekinna segir Ólafur svo frá:

\footnotetext{
... Ég bað hann í guðs nafni að halda sinni góðu trú og gleyma ekki sínum catechismi pá sagði hann með stórum harmi: „Ekki, minn faðir. Deir hljóta nú að fara með kroppinn sem peir vilja en mína sál skal ég geyma mínum góða guði. ${ }^{63}$
}

Trúskiptin purftu ekki að rista djúpt og samfélagið sem bauðst í Norður-Afríku hafði sína kosti, jafnvel fyrir ófrjálsan mann. Pannig var um William Okeley sem var fangi í Algeirsborg árin 1639-1644. Hann komst í eigu góðlynds húsbónda sem tók honum sem syni sínum og var hinn alúðlegasti á allan hátt. Okeley sá tækifæri til að flýja en fékk bakpanka og samviskubit yfir pví að yfirgefa svo góðan mann og hugleiddi stöðu sína:

Ég gæti hugsanlega fundið verri vistarveru í Englandi par sem borgarastríð var nú skollið á og pað með svo mikilli heift að varla pyrmdi hver annars lífi pó væri sá af sömu pjóð og kannski blóðskyldleika. Ef ég varð svo uppnuminn af pví að minnast á fósturland pá má vissulega segja að land okkar sé hvarvetna par sem okkur vegnar vel og heimurinn allur sé heimkynni pess sem unir sér hvar sem er í veröldinni. ${ }^{64}$

Okeley hugleiddi einnig frelsið og kvað sig sem præl frjálsari en margan „frjálsan“ mann. Engu að síður var niðurstaða hans sú að flýja pví að frelsi hans væri háð duttlungum pess sem væri eigandi hans hverju sinni.

Af íslensku trúskiptingunum fer ekki mörgum sögum en pó eru til nokkrar upplýsingar um prjú peirra. Hér verður aðeins staldrað við konu frá Vestmannaeyjum sem var forsmáð af grönnum sínum í Eyjum fyrir vikið og síðan var lítið talað um hana opinberlega pó að hún hefði lengi vakið forvitni og pó einkum nú síðustu áratugina. Anna Jasparsdóttir hét pessi kona og var hertekin ásamt föður sínum, Jaspari Kristjánssyni, sem var danskur, í ráninu 1627. Um móðurina er ekki getið. Anna var gift kona en eiginmaðurinn, Jón Oddsson, komst undan herleiðingu. Pau hjónin bjuggu á bænum Stakkagerði en par voru einnig skráð önnur hjón, Eyjólfur Sölmundarson og Guðríður Símonardóttir sem pekktust er allra hinna herleiddu. Jón Oddsson var allstöndugur eins og sjá má af pví að hann gaf drjúgt til endurbyggingar Landakirkju áratuginn eftir að Tyrkir brenndu hana. ${ }^{65}$

Anna Jasparsdóttir skýst inn í samtímaheimildirnar af einni ástæðu: Eiginmaður hennar varð leiður á biðinni eftir eiginkonunni og vildi festa ráð sitt á nýjan leik. Petta kallaði á skrif og skýringar.

Degar Jaspar Kristjánsson kom aftur til Íslands skráði hann merkilegt bréf um herleiðingu sína og dótturinnar að beiðni Gísla Oddssonar biskups í Skálholti og fyrir milligöngu áðurnefnds Kláusar Eyjólfssonar. Hann segir par að sami maður hafi keypt sig og Ólaf Egilsson ásamt konu og börnum. Dóttur sína hafi annar maður keypt og hafi hún grátið yfir pví að vita engin skil á föður sínum. Húsbóndi hennar hafi pá haft uppi á honum og keypt hann lausan fyrir 300 „Stöchvonachten“. Petta var mikið fé, samsvaraði svipaðri upphæð í ríkisdölum, og var meira verð en nokkur

${ }^{62}$ Natalie Zemon Davis, Trickster Travels: A Sixteenth-Century Between Worlds, New York: Hill and Wang, 2006, bls. $188-189$.

${ }^{63}$ Ólafur Egilsson, „Ferðasaga síra Ólafs Egilssonar“, bls. 156.

${ }^{64}$ William Okeley, „Ebenezer; or A Small Monument of Great Mercy, Appearing in the Miraculous Deliverance of Will“, Piracy, Slavery, and Redemption: Barbary Captivity Narratives from Early Modern England, ritstj. Daniel J. Vitkus, Columbia: Columbia University Press, 2001, bls. 124-192, hér 170.

${ }^{65}$ „Skýrsla um endurbygging Landakirkju eptir Tyrkjabrunann og um gjafir til hennar“, Tyrkjaránið á Íslandi 1627, bls. $397-$ 409, hér 403, 408 og 409. 
Íslendingur var keyptur á í útkaupaferðinni 1635-1636. Dessi húsbóndi, eigandi og velgjörðarmaður Önnu Jasparsdóttur hét Jús Hamet og var trúskiptingur frá Spáni sem var „prengt af sinni pápisku trú“, skrifar Jaspar.

En hvað hann er fyrir einn, pað veit ég gott verk gerði hann á mig sem sá maður sagði og skrifað stendur í Jóh. 9. kap.: Blindur var ég en nú sé ég, sagði hann. Svo segi ég: Fanginn var ég, nú er ég laus frá peirra höndum, svo lengi sem guð vill líða mig syndara. ${ }^{66}$

Í júnímánuði 1636 voru tveir Vestmannaeyingar komnir heim úr herleiðingunni, Hallur Porsteinsson og Porsteinn Ormsson. Heima í Eyjum sat Jón Oddsson sem hafði ekki séð konu sína, Önnu Jasparsdóttur, í níu ár, síðan hún var hertekin í Tyrkjaráninu. Líf hans hafði breyst og hann vildi festa ráð sitt á nýjan leik en til pess purfti Anna að vera horfin úr lífi hans með lögmætum hætti, látin eða turnuð. Fyrst var faðir Önnu beðinn að gera grein fyrir pví sem hann vissi frammi fyrir Gísla biskupi og Kláusi Eyjólfssyni lögsagnara. Hann skrifaði bréfið sem áður er nefnt, sem er eins og varnarrit fyrir Önnu og pó jafnframt fyrir trúskiptinginn Jús Hamet sem var „patrón“ hennar og nú barnsfaðir að pví er hann hermdi eftir Porsteini Ormssyni.

Hallur Dorsteinsson vottar pví næst að Anna sé „par vistföst í Tyrkjaríinu með fullkomnum samfélagsskap við einn tyrkneskan heiðingja og honum sampykk með sönnu hatri og óvild við pá kristnu ... Vissi ég seinast til hennar 1632 og vildi hún pá ei sjá íslenska kristna menn, pess heldur umgengni með peim að hafa“ ${ }^{67}$ Dorsteinn Ormsson staðfesti síðan að vitnisburður Halls Porsteinssonar væri réttur.

Erlendur Ásmundsson vottaði pessa gjörninga og bætti efnislega nokkru við, eins og til áherslu, pó að hann væri ekki sjónarvottur heldur milliliður:

Annað er pað hún gengur par fram í mesta meðlæti, klædd í pelli og gulllegum purpura, ei viljandi sjá íslenska kristna menn, enn síður við pá tala. ${ }^{68}$

Vitnaleiðslurnar voru loks fullkomnaðar með úrskurði Kláusar Eyjólfssonar um að Jón Oddsson væri í fullum rétti til að giftast. ${ }^{69}$

Varasamt er að taka vitnisburði sveitunga Önnu bókstaflega. Vel má hugsa sér að peir hafi verið reiðubúnir að taka sterkt til orða til að tryggja Jóni Oddssyni framgang sinna hjúskaparmála. Đegar að er gáð kemur hvergi fram berum orðum að Anna hafi turnast, p.e. skipt um trú. pað er hins vegar sterklega gefið í skyn með pví að segja að hún búi með heiðingja, eigi börn með honum, vilji ekki umgangast kristna menn og engin von sé til pess að hún komi aftur. Með pví að láta hana líta út sem frjálsan geranda var ekki hægt að afsaka hana með pví að hún hefði verið pvinguð. Hún hafði sjálf sagt sig úr guðs lögum og kristinna manna.

Hjónaband með (pvinguðum) trúskiptingi hefur verið vænlegri kostur en að gifta sig gamalgrónum múslíma par sem möguleikar voru meiri til að ástunda trú sína í leynum ef líkt háttaði hjá makanum. ${ }^{70}$ Konur héldu að jafnaði fastar og lengur í upprunatrúna en karlmenn, segir Hilda Nissimi, sem borið hefur saman trúskiptinga á nokkrum landsvæðum og mismunandi tímabilum. Pær létu síður undan prýstingi enda hefði prýstingur á pær að jafnaði verið minni en á karla. Petta á við um „nýja

\footnotetext{
${ }^{66}$ „Bréf Jespers Kristjánssonar til Gísla biskups Oddssonar í Skálholti“, Tyrkjaránið á Íslandi 1627, bls. 421-423, hér 422.

${ }^{67}$ Guðrún Ása Grímsdóttir, „Úr Tyrkjaveldi og bréfabókum“, Gripla 9/1995, bls. 7-44, hér 24.

${ }^{68}$ Sama rit, bls. 25.

${ }^{69}$ Sama rit, bls. 26.

${ }^{70}$ Hilda Nissimi, „Religious Conversion, Covert Defiance and Social Identity: Narrations of Conversion and the Creation of the Modern Renegade“, Numen 4/2004, bls. 367-406, hér 384.
} 
Mára“ (Moriscos, Moriscas) á Spáni og í Portúgal, húgenotta í Frakklandi og gyðinga í Íran, segir Nissimi. ${ }^{71}$ Pessi niðurstaða er ekki í samhljómi við áhyggjur útkaupamanna sem lögðu oft áherslu á að leysa konur par sem peim væri hættara við trúskiptum en körlum.

\section{Trúverndarskylda yfirvaldanna}

Tyrkjaránið varðaði mest pau sem brottnumin voru og aðstandendur peirra. En atburðurinn var ekki einkamál heldur snerti yfirvöldin í ríkinu, bæði kirkju og konungsvald. Í Danmörku ríkti Kristján konungur IV sem hafði svarið eið sinn 1596 sem konungur Danmerkur og par með Íslands. Í samningi konungs við aðal og borgara fjallaði fyrsti liður um trúarlegar skyldur hans sem konungs og verndara og yfirvalds kirkjunnar að lútherskum skilningi par sem greint er milli andlegs og veraldlegs valds. „Fyrst og framar öllu viljum vér og skulum elska og tigna hin almáttuga Guð og hans heilaga orð ...“.72 Áherslan er síðan á skóla og kirkjur par sem eiga að vera í forsvari vel menntaðir menn. Í pessu felst einnig sálarheill pegnanna og víst er að hún var Kristjáni konungi hugleikin af ýmsum ástæðum. Trúarsannfæring hans virðist vera sönn og staðföst en pað var einnig metnaðarmál hans sem evrópsks konungs og lúthersks forystumanns í samkeppni við Svíakonung að standa sig í pessu verndarhlutverki. „Tyrkjaógnin“"var honum einnig hugleikin eins og sjá má á margra daga krýningarhátíð Kristjáns par sem sigurinn yfir Tyrkjum var settur á svið og leikinn á götum Kaupmannahafnar. ${ }^{73}$

Til vitnisburðar um trúarskyldu Kristjáns IV er bréf sem hann skrifaði æðsta embættismanni sínum á Íslandi, Holgeir Rosenkranz, árið 1630.

\footnotetext{
... par sem vér höfum fregnað að Tyrkinn hafi komið til lands vors, Íslands, og numið brott nokkra af íbúunum par biðjum vér pig og óskum að pú með prestastéttinni og helstu mönnum landsins finnir leið, með hjálp hinna efnameiri, til að hjálpa megi pessum föngum og útleysa pá svo að peir verði ekki eftir í tyrknesku týranníi og pvingist í tilbót að afneita Kristi. ${ }^{74}$
}

petta er meira en orðskrúð pví brátt var tekið til við að safna fé og skipuleggja ferð til að leysa fólk út í Algeirsborg. Í seinni tíma söguskrifum og kennslubókum hefur oft verið sagt að seint hafi verið brugðist við og árangurinn verið lítill. Seinu viðbrögðin skýrast með pví að konungssjóður var nær gjaldprota eftir ósigurinn við keisaraherina 1626-1627 og fé purfti að safna í tóman sjóð. Skipulagningin var flókin par sem dönsk stjórnvöld höfðu litla reynslu af Miðjarðarhafinu og par af minnsta af Norður-Afríku.

Viðleitni konungs til að leysa pegna sína úr herleiðingu hafði sterka trúarlega hvata, bæði af samkristilegum og lútherskum rótum, og jókst af veraldlegum metnaði og hagsmunum konungsvaldsins. Að kristilegum skilningi var Kristur endurlausnari mannkyns og fyrir kom, einkum á fyrri hluta miðalda, að endurlausnin væri beintengd að orðalagi við lausnargjald sem greitt var til að leysa præla úr ánauð. Sömu grísku

\footnotetext{
71 Sama rit, bls. 390-395.

72 „Först wille och skulle wy offuer allting elske och dyrcke den allsommechtigste Gudt och hans hellige ordt ... “ Christian 4.s håndfæstning, 17. august 1596; danmarkshistorien.dk, Historisk Afdeling ved Institut for Kultur og Samfund, Aarhus Universitet, sótt 16. okt. 2020 af

https://danmarkshistorien.dk/leksikon-og-kilder/vis/materiale/christian-4s-haandfaestning-17-august-1596/.

73 Bent Holm, Tyrk kan tammes. Osmannere på den danske scene 1596-1896, Kaupmannahöfn: Multivers, 2010, bls. 37-61.

74 „Bréf Kristjáns konungs fjórða til Holgeirs höfuðsmanns Rosenkrantz um útlausn íslenzkra fanga frá Tyrkjum“, Tyrkjaránið á Íslandi 1627, bls. 384-385, hér 384.
} 
orðin voru notuð um endurlausn og lausnargjald (gr. lytron) af tvennu tagi. ${ }^{75}$ Ekki er að efa að Kristján konungur IV hafði Krist (sem nafn hans vísar til) í hug og hjarta í stjórnarstörfum sínum. Um pað vitnar sýn hans um hinn pjáða Krist, eins og áður hefur verið nefnt. ๖að örlar einnig á peirri hugsun að Kristján sé endurlausnari pegnanna sem frelsar pá frá kapólskri villutrú í átökum við keisaraherinn sem hann tapaði fyrir (en tókst pó að ná tiltölulega góðum samningum við eftir ósigurinn). Um petta vitna flugblöð og dreifirit frá tíma keisarastríða og Tyrkjaráns sem bandaríski sagnfræðingurinn Paul Douglas Lockhart hefur rannsakað. ${ }^{76}$

Konungsvaldinu, og einkum Kristjáni IV sjálfum, var í mun að koma fram sem gæslumaður trúar og pegna. Lúthersk kenning boðaði hlýðni við yfirvöld en í kenningunni voru einnig aðrir tónar sem settu konungana lægri en Jesú Krist og sýndu pá jafnvel fáfengilega. bessu má finna stað í víðlesnu riti á lútherska svæðinu, Eintali sálarinnar við sjálfa sig eftir pýska siðbótarmanninn Martin Moller. Bókina pýddi Arngrímur Jónsson lærði og kom hún út á Hólum 1599 og fimm sinnum eftir pað. Píslarsaga Krists er par rakin og hugleidd. Út frá samtali Pílatusar og Krists, par sem hinn síðarnefndi segir ríki sitt ekki vera af pessum heimi og að hann sé kominn í heiminn til að bera sannleikanum vitni, hugleiðir Martin Moller:

1. Jarðneskir kóngar ríkja og festa sitt ríki með stríðsmakt og mikilmennsku. En pú ert, drottinn, kóngur sannleikans. ---

2. Jarðneskir kóngar ríkja og peirra góss og gáfur eru jarðlegar og fáfengilegar. En pú ert kóngur á himnum og ert ríkur af sannleikanum peim aumu til hjálpar. Guð, pinn faðir, hefur pig sent til að kenna fávísum sundurknosuð hjörtu að græða, peim herteknu lausn og frelsi að boða, náðartíð drottins að kunngjöra og pann dag hefndar drottins öllum sorgfullum til huggunar. ${ }^{77}$

Trúarkenningin kenndi pegnunum pannig að virða veraldleg yfirvöld en einnig að sjá tilveruna í pví ljósi að hið æðsta yfirvald væri undirsett lausnaranum mikla og væri einungis jarðlegt og fáfengilegt.

\section{Heildartúlkun á atburðunum}

Ekki er vitað hvaða skilning hver einstaklingur sem hernuminn var lagði í atburðina. „Vér hljótum vort harmabrauð að eta með rennandi tárum,“ segir í bréfi íslenskra fanga í Algeirsborg 1635. ${ }^{78}$ Pá hafði sótt á marga að leita skýringa og setja atburðina í stærra samhengi. Um pað höfum við einungis beinar heimildir frá hinum menntuðu og skólalærðu.

pegar í miðju atburðanna í Vestmannaeyjum virðist annar prestanna par, Jón Porsteinsson, hafa gengið inn í píslarsöguna, sem kalla má eitt hið æðsta viðmið. Hann flýði undan árásarmönnum í helli við ströndina og las og söng guðsorð með heimilisfólki sínu. Flokkur vígamanna fann pau í hellinum og hjó foringi peirra Jón prjú högg til bana og mælti hann yfirveguð orð undan hverju höggi. Lokaorð hans voru: „Фað er nóg! Herra Jesú, meðtak pú minn anda. “79 pegar Jón var allur tók Margrét, kona

\footnotetext{
${ }^{75}$ Einar Sigurbjörnsson, Credo: Kristin trúfrađi, Reykjavík: Háskólaútgáfan og Guðfræðistofnun, 1989 (kafli 12: Friðpægingarverk Jesú), bls. 271.

${ }^{76}$ Paul Douglas Lockhart, „Dansk propaganda under Kejserkrigen 1625-29“, Historie/Jyske Samlinger 2/1998, bls. 222248.

${ }^{77}$ Martin Moller, Soliloqvia de Passione Jesu Christi: pað er Eintal sálarinnar við sjálfa sig, Pórunn Sigurðardóttir bjó til útgáfu og ritaði inngang, Reykjavík: Bókmennta- og listfræðastofnun Háskóla Íslands og Guðfræðistofnun Háskóla Íslands, 2019, bls. 127. Feitletrun mín (bH).

${ }^{78}$ Bréf fanganna úr Algeirsborg, bls. 427.

${ }^{79}$ Kláus Eyjólfsson, „Frásögn“", C-gerð, Tyrkjaránið á Íslandi 1627, bls. 56-74, hér 68.
} 
hans, traf af höfði sér og batt um blóðugt höfuð eiginmanns síns. ${ }^{80}$ Líkingin við pyrnikórónu Krists er nærtæk.

Sá sem skráði pessa frásögn fyrstur, og aðrir byggja síðan á, var títtnefndur Kláus Eyjólfsson, sem var systursonur séra Jóns. Virðist hér sem Kláus hafi sniðið frásögn sína að píslarsögu Krists og er í allmörgum afskriftum bætt við Júdasarminni. Er foringinn par nafngreindur, Dorsteinn sá er vísaði ránsmönnum sjaldgæfa leið til uppgöngu í Vestmannaeyjum og í fáeinum afskriftum að sá hinn sami hafi áður verið „verkapjónn“ séra Jóns. ${ }^{81}$ Kláus fellir frásögn sína að píslarsögunni en Jón Dorsteinsson hefur að líkindum einnig hagað gerðum sínum hinar síðustu stundir að píslarsögunni og peim mörgu skrifum í samtíma sínum um ,að lifa guðlega og deyja kristilega". 82

Kláus Eyjólfsson hafði ekki sagt sitt síðasta orð um Tyrkjaránið með skriflegri frásögn sinni. Hann og danski kaupmaðurinn Níels Klemensson gáfu til kirkjunnar á Krossi í Landeyjum altaristöflu árið 1650 sem lesa má sem vísun í túlkun Lúthers á Jóhannesarguðspjallinu og jafnframt vísun í píslarvætti Jóns Porsteinssonar í Vestmannaeyjum. Par má skilja sem náðst hafi ákveðin lokun og sigur sem ekki krefst hefndar. Pessi túlkun, í myndrænu formi, er einstök á Íslandi. Taflan er máluð í Danmörku en færð hafa verið rök fyrir pví að gefendurnir og fleiri aðstandendur hafi haft hönd í bagga með inntaki hennar og útfærslu. Ekki verður hér farið nánar út í rannsóknir á altaristöflunni á Krossi en vísað í önnur rit. ${ }^{83}$

Tyrkjaránið var ný reynsla og ófyrirséð, meira áfall en annað pað sem dunið hafði á landinu í manna minnum. Magnús Sigfússon prestur orti „Harmagrát yfir ósköpum Íslands“ pegar árið 1627 var runnið sitt skeið. Hann taldi prjár hörmungar hafa gengið yfir landið, hina fyrstu að herra Guðbrandur Porláksson biskup andaðist. Harmur sá var pó ekki stór pví að hann skildi vel við sína „skipstjórn“ og var nú leystur frá „,sorgarörkinni“. Annað áfall var farsótt sem gekk í landinu svo að „mætir buðu margir fljótt/menn og kvinnur góða nótt“. Magnús hefur pá afstöðu til dauðans sem boðuð var á hans tíma og pessi „ósköp“ eru pví viðráðanleg:

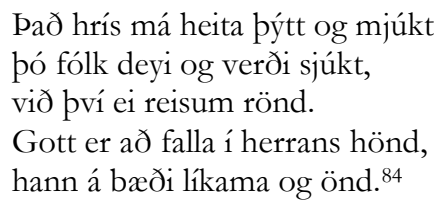

Víg sr. Jóns Porsteinssonar í Vestmannaeyjum var af pessum sama toga: „Ei parf pó lengur að aumka hann/pví er nú kominn í himna rann. “85 Hins vegar var hin priðja hörmungin, Tyrkjaránið, sálarháskinn vegna heiðinna manna, verra tjón: „,.. margur grimmur og guðlaus her/gengið hefur á landið vort hér. “86 Óttalegast var hlutskipti

\footnotetext{
${ }^{80}$ Sama rit, bls. 68.

${ }^{81}$ Kláus Eyjólfsson, „Frásögn“, D-gerð, Tyrkjaránið á Íslandi 1627, bls. 74-90, hér 78.

82 Dorsteinn Helgason, „Að lifa guðlega og deyja kristilega: Um píslarvætti Jóns Borsteinssonar í Vestmannaeyjum“, Áhrif Lúthers: Sidaskipti, samfélag og menning i 500 ár, ritstj. Hjalti Hugason, Loftur Guttormsson og Margrét Eggertsdóttir, Reykjavík: Hið íslenska bókmenntafélag, 2017, bls. 299-333.

${ }^{83}$ Ég hef oft og víða fjallað um altaristöfluna á Krossi, fyrst pó hér: Porsteinn Helgason, „Sverð úr munni Krists á Krossi“, Arbók. Hins islenske fornleifafélags 2000-2001, 2003, bls. 143-170. Á leitarvélum má finna fleiri birtingar.

${ }^{84}$ Magnús Sigfússon, „Harmagrátur Síra Magnúsar Sigfússonar yfir ósköpum Íslands“, Tyrkjaránið á İslandi 1627, bls. 501505 , hér 502.

85 Sama rit, bls. 503.

${ }^{86}$ Sama rit, bls. 502 .
} 
Ólafs Egilssonar og allra hinna sem hertekin voru „hjá heiðnum lýð“. ${ }^{87}$ Petta hlutskipti var svo nýtt og fordæmalaust að pað féll ekki auðveldlega að heimsmyndinni sem gat ráðið við farsóttir og dauðdaga fólks á heimaslóð. Hvernig var hægt að lifa guðlega í Barbaríinu og deyja kristilega á heiðinni jörð?

ధó að Tyrkjaránið væri stórt í sniðum, óvænt og fordæmalaust, var ekki um annað аð ræða en að reyna að skilja pað peim grunnskilningi sem almennur var og fest hafði rætur í kristnum heimi. Рað er sú kenning, hugsun og tilfinning að áföll og hörmungar væru verðskulduð refsing fyrir syndir mannanna. Kenningin er flókin og erfitt að segja til um hve almenn hún var í hugmyndaheimi samtímamanna. Í almennum kristnum skilningi, a.m.k. frá dögum Páls postula, var heimurinn syndlaus og saklaus í upphafi en höggormurinn í Paradís tældi Evu og hún síðan Adam til að brjóta lögmál guðs og sundra pannig hinu upprunalega samræmi tilverunnar. Pjáning og dauði komu í heiminn og inn í pann heim, pann synduga heim, fæðast allar mannverur upp frá pví og erfa upprunasyndina. Hlutverk Jesú Krists var að taka syndina á sig og deyja fyrir mannkynið, friðpægja fyrir mennina, og peirrar friðpægingar getur mannskepnan orðið aðnjótandi með iðrun og trú. ${ }^{88}$

Skólagengnir og guðfræðilega lærðir menn á Íslandi á sautjándu öld höfðu meðtekið pessa kenningu. Баð kemur til dæmis skýrt fram í bréfi sem Jón Jónsson frá Grindavík skrifaði til foreldra sinna (og fyrir hönd bróður síns einnig) frá Algeirsborg árið 1630. Hann hafði gengið í Skálholtsskóla og skrifaði margt fyrir Íslendinga í herleiðingunni. Í bréfinu tilgreinir hann kvæði eða sálm sem „ég segi svo jafnlega.“ par eru pessar hendingar:

\footnotetext{
Í saurgan getinn er ég einn, enginn maður kann fæðast hreinn af syndum spilltu sæði ...

Og í næsta erindi ítrekar Jón:

$$
\begin{aligned}
& \text {... sjá pú ég ber } \\
& \text { syndir með mér } \\
& \text { sjúkur frá móðurlífi. }{ }^{89}
\end{aligned}
$$
}

Kenningin um erfðasynd, friðpægingu og náð fyrir trú er engu að síður stór biti að kyngja og krafðist bæði sannfæringar og lærdóms. Hún var ekki — og hefur ekki verið ${ }^{90}$ — óumdeild en var boðuð af fullum krafti á sautjándu öld í danska ríkinu og eru Passíusálmar Hallgríms Péturssonar ein skýrasta og fegursta útlegging á kenningunni. Kenningin hljómar harkalega en er hugsanlegt að hún hafi verið fólki til huggunar og styrktar á sautjándu öld?

Kenningin um áföll sem verðskuldaða refsingu setti reynslu manna í samhengi og gaf peim tilgang. Áfallið var pannig skiljanlegt og beindist ekki einvörðungu að persónunni sem fyrir pví varð heldur varðaði mannkyn allt. Djáningin er pannig hlutskipti

\footnotetext{
${ }^{87}$ Sama rit, bls. 503.

${ }^{88}$ Einar Sigurbjörnsson, Credo (kafli 7: Um illskuna og kafli 12: Friðpægingarhlutverk Jesú).

${ }^{89}$ Jón Jónsson, bréf til foreldranna, bls. 381.

${ }^{90}$ Höfundar hins svokallaða „nýja rétttrúnaðar“ sem komu fram eftir fyrri heimsstyrjöld héldu fast í kenninguna (î mismunandi myndum), sjá t.d. Benjamin Burkholder, „Violence, Atonement, and Retributive Justice: Bonhoeffer as a Test Case“, Modern Theology 33:3/2017, bls. 395-413.
} 
mannsins, syndin er tákn um rof í tilverunni sem allir líða. ${ }^{11}$ Við petta bættist krossganga Krists sem ekki var einasta friðpæging og endurlausn (með nokkuð flóknum hætti) heldur gátu hin pjáðu samsamað sig Kristi í píslum hans.

Dessari hugsun finnum við stað í skrifum í samtíma Tyrkjaránsins. Guðríður Símonardóttir skrifaði úr herleiðingu sinni í Algeirsborg að hana og „barnkind“ hennar hefði Tyrki keypt

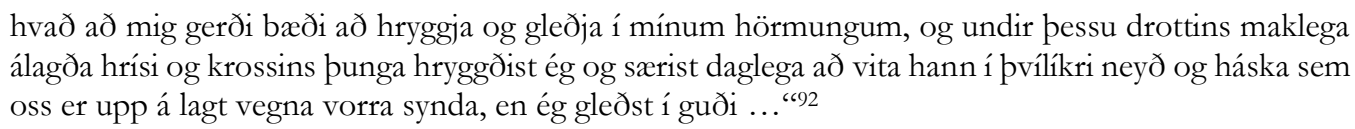

Parna er hinn „rétti“ skilningur útfærður í sendibréfi til eiginmanns Guðríðar. Áðurnefndur Jón Jónsson frá Grindavík skrifaði frá Alsír um „forpént herleiðslu- og útlegðarstraff“ sitt og bróður síns. ${ }^{93}$ Engu að síður hvílir Jón ekki í pjáningunni og straffinu heldur vonar að pað „fái góðan enda“. Og hann byggir iðrun sína ekki eingöngu á hinni almennu synd og sekt heldur biðja peir bræður foreldra sína fyrirgefningar „okkar pverbrotið sinni, óhlýðni, barnæsku- og ungdómsbrest.“94

Kenningin um hlutverk pjáningarinnar, refsingarinnar og endurlausnarinnar býður upp á ákveðin vandamál. Hvernig stendur á pví að sumu fólki er refsað með stórfelldum hætti, með hamförum og dauða, en annað fólk lifir stóráfallalaust? Hinn rétttrúaði segir: Við erum öll sek og eigum straffið skilið — en guði sé lof fyrir að við sluppum. Petta kom oft til tals og reyndu lærðir menn að árétta pessa kenningu: „Syndgast höfum ei síður en peir/sem pó hafa nú straffast meir ...", yrkir sr. Magnús Sigfússon og bætir við pakklæti fyrir að landsmenn hafi ekki allir orðið fyrir árásinni. ${ }^{95}$

Séra Jón Jónsson, prestur og skáld á Melum í Melasveit, var elsti sonur Jóns Porsteinssonar í Vestmannaeyjum, pess sem veginn var, og lagðist pví refsingin hart á hann, að missa föður sinn og sjá á eftir móður sinni, systur og bróður í herleiðingu. Engu að síður er afstaða hans pessi, a.m.k. í ljóði:

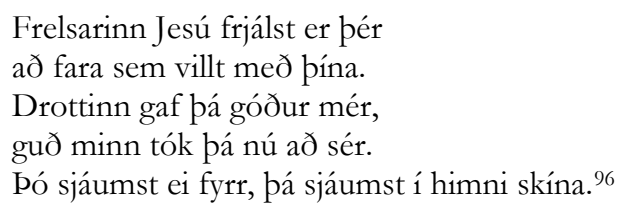

Jón afsakar sig fyrir að fjalla um pað sem stendur honum svo nærri en hann vitnar einnig í orð Krists (Lúk 13.4-5) sem hafa almenna skírskotun. Turninn í staðnum Sílóam féll á átján manns og banaði peim en Jesús spurði: „,... haldið pér að peir hafi verið sekari en allir peir menn sem í Jerúsalem búa? Nei, segi ég yður, en ef pér takið ekki sinnaskiptum munuð pér allir farast á sama hátt." Jón prestur og skáld orðar pað svo: „Ekki verri en aðra pá/úrskurðaði Kristur ...".97

Syndakenningin var flókin og vafðist ekki aðeins fyrir almenningi heldur einnig hinum lærðustu. Dannig glímdi Gísli Oddsson biskup í Skálholti við ýmis álitamál sem komu upp í Vestmannaeyjum eftir ránið par sem makar hertekinna sem sluppu

\footnotetext{
${ }^{91}$ Arnfríður Guðmundsdóttir, „Ekki eins og pað á að vera: Merking syndahugtaksins í kristinni trúarhefð fyrr og nứ, Ritið 3/2020 bls. $15-38$.

${ }_{92}$ Guðríður Símonardóttir, bréf til Eyjólfs eiginmanns hennar, Tyrkjaránið á Íslandi 1627, bls. 419-421, hér 420-421.

${ }^{93}$ Jón Jónsson, bréf til foreldranna, bls. 373.

${ }^{94}$ Sama rit, bls. 373.

${ }^{9}$ Magnús Sigfússon, „Harmagrátur “, bls. 504.

96 Jón Jónsson, „Harmavottur“, Tyrkjaránid á Íslandi 1627, bls. 506-515, hér 509.

${ }^{97}$ Sama rit, bls. 510.
} 
höfðu leiðst til sambúðar við nýja einstaklinga án pess að hjónaband peirra væri úrskurðað ógilt vegna dauða, trúskipta eða andláts makans. Hlutverk biskups var að halda eyjabúum frá syndsamlegri sambúð en hann gerir sér grein fyrir vandanum og kastar fram spurningu um syndina á stað sem hafði orðið fyrir svo miklu áfalli auk skipskaða og manntjóns undanfarinn tíma:

Ég vil hér ekki tala um sára skelfing samviskunnar sem sumar manneskjur (mest frómar) fá af ýmsum og allitlum tilefnum. Par um eru eftirdæmin ljós, bæði forn og ný. Par fyrir: Ef sá réttláti hjálpast varla, hvað vill pá verða af peim óguðlega? ${ }^{98}$

Svipaðar hugleiðingar koma fram í Ræningjarímum séra Guðmundar Erlendssonar í Felli í Skagafirði:

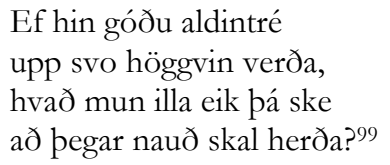

Upp kom sú hugsun að Vestmannaeyingar hefðu verið syndugri en annað fólk og pví verðskuldað pessa refsingu fremur en aðrir. Guðmundur vísar pessari hugsun frá, neitar að drottni hafi síður hugnast „,ś eyja lýður“ en okkur (Norðlendingum?) og vitnar í ritningarstaðinn um turninn í Sílóam. Petta segir Guðmundur í „Ræningjarímum“ sínum. 100 Í priðju rímu gengur Guðmundur skrefinu lengra í umtali um Vestmannaeyinga:

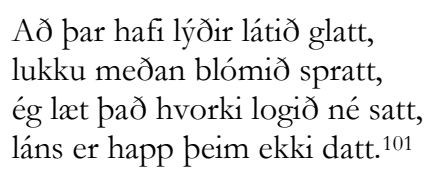

Guðmundur bætir pví við að séra Jón Dorsteinsson hafi áminnt fólkið en var fyrir pað hafður að spotti „,sem spámann hvers á sinni jörð.“ Jón hafi verið svo góður hirðir að „óguðlegir“ [Vestmannaeyingar] „1́ iðrunarleysi inni byrgðir“" hafi ekki verðskuldað hann. ${ }^{102}$ Hins vegar vill hann ekki trúa pví sem sagt sé að fólkið í Eyjum hafi tekið upp fyrra líferni. Ef svo væri „er pví annað eymda ping/að eflausu stefnt um kring. “103

Hér er komin trúarleg og kenningarleg klípa: Refsing guðs er jafnan verðskulduð og peir sem fyrir henni verða eru ekki sekari en aðrir. Samtímis geta menn safnað syndum að höfði sér og pá er „eymda ping“ yfirvofandi. Hver er pá sekt og refsing einstaklingsins? Önnur klípa er sú hvort rétt sé að berjast gegn peim sem guð „,notar“ til að refsa mönnunum, í pessu tilviki Tyrki. Lúther pótti framan af að svo væri ekki og hlaut bannfæringu Leós X páfa meðal annars vegna peirra ummæla, að eigin sögn Lúthers: „Að berjast gegn Tyrkjum er jafngilt og að veita Guði mótspyrnu sem vitjar rangsleitni okkar með pessu hrísi. “"104 Petta var afstaða mín á sínum tíma, ritar Lúther:

98 Gísli Oddsson, „Til Vestmannaeyja enn einu sinni í Jesú nafni“, bréf skrifað í Skálholti 16. okt. 1636; Guðrún Ása Grímsdóttir, „Ur Tyrkjaveldi og bréfabókum“, bls. 28. Sjá einnig Reisubók séra Olafs Egilssonar og aðrir textar um Tyrkjaránið 1627, Már Jónsson og Kári Bjarnason bjuggu til prentunar, [Selfossi]: Bókaútgáfan Sæmundur, 2020, bls. 285-287.

99 Guðmundur Erlendsson, „Ræningjarímur“, bls. 467.

100 Sama rit, bls. 476.

101 Sama rit, bls. 482-483.

102 Sama rit, bls. 481.

103 Sama rit, bls. 483.

104 Martin Luther, „On War Against the Turk“, Luther's Works 46, The Christian in Society 3, ritstj. Robert C. Schultz, Philadelphia: Fortress Press, 1967/1988, bls. 162. Pýðing höfundar (bH). 
„En pað er ekki sanngjarnt að gleyma hvernig ástandið var pá og hverjar forsendur og röksemdir mínar voru og taka orð mín síðan og beita peim á annað ástand pegar pessar forsendur og röksemdir eru ekki fyrir hendi." "105

Samtímamenn áttu ekki svör við öllum trúar- og tilvistarspurningum sem Tyrkjaránið vakti. Jón Jónsson frá Grindavík, hinn skólalærði, reyndi að sjá pjáninguna sem guðs vilja en „hvað pínum órannsakanlegum vilja hefur til gengið að líða pað vondir menn skulu mega yfirráð hafa á pínum eigin börnum“ — pað vissi guð einn sjálfur. Og betra hefði verið fyrir Helga bróður hans að eignast hlutskipti Betlehemsbarnanna (sem myrt voru að undirlagi Heródesar) en að líða kvalir og vera „,af vegi hrundið.“ Guðstraustið er engu að síður lokaniðurstaða Jóns: „En guð mun pér miskunnsamur vera pví hans miskunn er ný hvern morgun."106

Fyrir marga á sautjándu öld og löngum síðar var eilífa lífið hin síðasta huggun (stundum einnig hin fyrsta). Í henni fólust endurfundir ástvina eins og Jón, sonur Jóns píslarvotts, orti og áđur er vitnað til: „Đó sjáumst ei fyrr, pá sjáumst í himni skína." Á sautjándu öld, eins og síðar og einkum fyrr, bjuggust sumir við heimsslitum og hinum efsta dómi, sumir með ótta í sinni og aðrir með fögnuði. Đá yrði réttlætinu endanlega fullnægt og eilífur fögnuður myndi ríkja. Svo orti sr. Magnús Sigfússon: „... höfum síst við heiminn lag,/hugsum um pann síðasta dag. “107

Ein er vor huggun eftir stærst,

af pví rís vor gleðin hæst,

að pó ami margt

og á oss detti hrísið hart,

herrans lúður kalla mun. ${ }^{108}$

Huggunin sem fólst í eilífri himnavist virðist hafa dugað mörgum en ekki öllum. Um pað vitnar Einar Sigurðsson, skáld og prestur í Eydölum (sem stöðvaði framsókn ránsmanna 1627 með kveðskap, segir sagan). Pegar dóttir hans og Ólafar konu hans lést af barnsförum reyndist Einar „hugarsterkur/af herrans orði/um dýrðlegan afgang/dóttur sinnar." "109 Ólöfu konu hans var petta ekki nægilegt. Einar ber saman viðbrögð peirra við barnamissi. Hann er einn til frásagnar en dregur upp skýra mynd af ólíku hjartalagi.

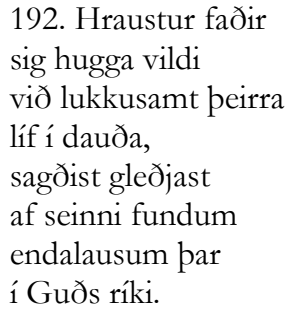

193. Angursstundir
oft Óluf reyndi
börn hennar pá
burt langt fóru
en allra sárast
ef pau deyðu
pví innri hrellingar
yfir að runnu. ${ }^{110}$

Einar skýrir trúartraust sitt sem hraustleikamerki en að Ólöf hafi verið „ker hið veika“, og „hugveik stundum“ en einnig má líta á petta sem mismunandi afstöðu til trúarhugsunar sem viðbrögð í áfalli.

105 Sama rit, bls. 162 .

106 Jón Jónsson, bréf til foreldranna, bls. 375.

107 Magnús Sigfússon, „Harmagrátur“, bls. 501.

108 Sama rit, bls. 501.

109 Einar Sigurðsson í Eydölum, „Ævisöguflokkur Einars í Eydölum“, Ljódmali, Jón Samsonarson og Kristján Eiríksson bjuggu til prentunar, Reykjavík: Stofnun Árna Magnússonar, 2007, bls. 135 (erindi 175).

110 Sama rit, bls. 137. 
Eins og tilvitnanirnar hér að framan bera með sér var algengt að setja huggunarorð í bundið mál. Pau voru auk pess ekki ætluð til lestrar í hljóði hvers og eins líkt og nú tíðkast heldur til að syngja eða kveða. Algengt er í handritum að lagboði sé settur við efnið. Dannig má syngja Harmagrát Magnúsar Sigfússonar við lagið „,Mitt hjarta hvar til hryggist pú“ sem prentað er í Grallaranum. Flutningurinn fer fram í samfélagi, söngurinn hefur lækningarmátt. ${ }^{111}$ Dórunn Sigurðardóttir hefur ítarlega rannsakað og fjallað um hlutverk harmljóða á sautjándu öld. Eitt dæmi er sorgarljóð Jóns Einarssonar í Stærra-Árskógi sem missti konu sína og tengdaföður í sjóinn. Huggunaraðferð ljóðsins er í greiningu Dórunnar: „Til að yfirvinna harminn sem drukknun konu hans hefur valdið honum ætlar séra Jón að yrkja sorgarsöng og væntanlega syngja hann eða fara með sér til hugarléttis." "112 Almenn niðurstaða hennar um áhrif kveðskaparins til hugarléttis er pessi: „Textar í bundnu máli hafa aukið áhrifin, einkanlega ef hægt var að syngja pá við pekkt sálmalag. “113

рað er ekki auðvelt að setja sig í spor peirra sem töldu áföll vera verðskuldað straff fyrir syndugt mannkyn, peirra sem pótti „pýtt og mjúkt/pó fólk deyi og verði sjúkt“ og bjuggust jafnvel við heimsendi. Hættan á að framandgera trúarviðhorf fyrri tíma er vissulega fyrir hendi, að sýnast pau vera furðuleg eða ógeðfelld, í besta falli skringileg. Önnur hættan er sú að einfalda og alhæfa um trúarviðhorf. Af pví sem hér hefur verið sagt kemur fram að viðhorf voru ekki á eina lund í samtíma Tyrkjaránsins og siðferðileg og trúarleg álitamál voru tekin til umræðu. Höfðu pau viðhorf sem hér er lýst — um verðskuldað syndastraff — ekki lamandi áhrif og hlutu að leiða til aðgerðarleysis og uppgjafar? Nei, pví að umræða var greinilega mikil um viðbrögð við Tyrkjaráninu, hafist var handa við söfnun og sendiboðar fóru með ærinni fyrirhöfn til Norður-Afríku að semja um útlausn. Og hvatt var til samlíðunar:

\footnotetext{
Látum oss vakna, víst til sanns

vitjað hefur guð pessa lands.

Höfum ei hjartað steins.

Dó ekki líði allir eins,

annarra skulum kenna meins. ${ }^{114}$
}

Kristin guðstrú var mörgum, líklega flestum, ríkulegt veganesti í herleiðingunni. Sumt af hertekna fólkinu fann hins vegar aðra leiðarsteina sem leiddi pað til annarrar trúar og annars samfélags og pegar farsællega fór, var pað einnig samfélag peirra sem ekki höfðu hjarta steins.

\section{Lokaorð}

Af allri umfjölluninni hér á undan er ljóst að svarið við spurningunni um hvað trúarlegt hafi verið við Tyrkjaránið í samtíma pess verður einfalt: Trúin umlauk flestar hliðar málsins. Hið augljósa er að guðstrúin var sá hugmyndarammi sem markaði flesta stórviðburði og skilning manna á peim. Í pessu tilviki bættist margt annað við. Ránsmennirnir árið 1627 komu úr löndum múslíma og lengi hafði verið boðað að

\footnotetext{
111 Dórunn Sigurðardóttir og Porsteinn Helgason, „Singing the News in Seventeenth-Century Iceland: The Destruction of Magdeburg in 1631“, Quaerendo, 50:3/2020, bls. 310-336.

112 Dórunn Sigurðardóttir, Heiður og buggun: Erfiljóo, barmljöo og huggunarkvaedi á 17. öld, Reykjavík: Stofnun Árna Magnússonar 1 íslenskum fræðum, 2015, bls. 113.

113 Sama rit, bls. 116.

114 Magnús Sigfússon, „Harmagrátur“, bls. 503.
} 
íslam væri (í besta falli) skaðleg villutrú. Að skilningi samtímamanna voru hin herteknu pví í sálarháska. Að vísu voru margir íbúar Norður-Afríku, og ekki síst á árásarskipunum, kristnir Evrópumenn að uppruna en í sögurituninni voru peir taldir verstir pví að svikarinn sem gengur í lið með óvininum er versta skaðræðið.

pegar herteknu Íslendingarnir höfðu kynnst heimaborgum korsaranna runnu tvær grímur á sum peirra. Náttúruskilyrðin voru hagstæðari en heima, tækifæri gáfust til að komast í álnir og einnig par reyndist vera til fólk sem „ekki hafði hjarta steins“. Allmargir Íslendingar kusu pví að vera um kyrrt og taka upp trú og siði heimamanna — sem ekki purftu alltaf að rista djúpt. Mörg voru einnig pvinguð til að vera um kyrrt, einkum börnin.

Tyrkjaránið var áfall fyrir hin herteknu og pau sem eftir sátu og trúin reyndist mörgum, ef ekki flestum, mikil stoð. Hún setti áfallið í samhengi við pá bresti sem voru í samfélagi manna og samband peirra við guð, milli erfðasyndarinnar og pess hlutskiptis manna sem á eftir kom par sem enginn gat búist við að lifa áfallalaust. pjáninguna hafði Kristur borið og hann var í senn fyrirmyndin og lausnarinn.

Tyrkjaránið setti af stað röð aðgerða: frásagnir voru ritaðar og dreifðust 1 handskrifuðum afritum; kvæði, drápur og rímur voru kveðin, sungin og lesin og bænir beðnar; lausnarfé var safnað, stjórnkerfi virkjuð og samningamenn sendir út af örkinni.

Saknað var og grátið en ný von og kærleikur kviknaði, á Íslandi og í Norður-Afríku. Trúin og lífsviðhorfin hlutu eldskírn og komu hert úr prautinni hjá sumum en snerust á sveif með umhverfinu hjá öðrum. Engin voru ósnortin. 